\title{
Performance of viruses and bacteriophages for fecal source determination in a multi-laboratory, comparative study
}

\author{
Valerie J. Harwood ${ }^{\mathrm{a}, *}$, Alexandria B. Boehm ${ }^{\mathrm{b}}$, Lauren M. Sassoubre ${ }^{\mathrm{b}}$, Kannappan Vijayavel ${ }^{\mathrm{c}, \mathrm{l}}$, \\ Jill R. Stewart ${ }^{d}$, Theng-Theng Fong ${ }^{e}$, Marie-Paule Caprais ${ }^{f}$, Reagan R. Converse ${ }^{g}$, David Diston ${ }^{h}$, \\ James Ebdon', Jed A. Fuhrman', Michele Gourmelon', Jennifer Gentry-Shields ${ }^{\mathrm{d}}$, John F. Griffith ${ }^{\mathrm{k}}$, \\ Donna R. Kashian', Rachel T. Noble ${ }^{m}$, Huw Taylor', Melanie Wicki ${ }^{\text {h }}$
}

\footnotetext{
a Department of Integrative Biology, University of South Florida, Tampa FL 33620, USA

b Environmental and Water Studies, Department of Civil and Environmental Engineering, Stanford University, Stanford, CA 94305, USA

${ }^{c}$ Environmental Health Division, Ottawa County Health Department, Holland MI 49424, USA

d Department of Environmental Sciences and Engineering, Gillings School of Global Public Health, University of North Carolina, Chapel Hill, NC 27599-7431, USA

e Clancy Environmental Consultants, a Tetra Tech company. St Albans, VT 05478, USA

f Laboratoire de Microbiologie, MIC/LNR, Département Ressources Biologiques et Environnement, Unité Environnement, Microbiologie et Phycotoxines, Ifremer, ZI Pointe du diable, 29280, Plouzané, France

${ }^{g}$ Oak Ridge Institute for Science and Education, Oak Ridge, TN 37831

${ }^{\mathrm{h}}$ Federal Office of Public Health, 3003, Bern, Switzerland

i Environment \& Public Health Research Unit, School of Environment \& Technology, University of Brighton, Brighton BN2 4GJ, UK

${ }^{j}$ Department of Biological Sciences, University of Southern California, Los Angeles, CA 90089, USA

${ }^{k}$ Southern California Coastal Water Research Project, Costa Mesa, CA 92626, USA

' Department of Biological Sciences, Wayne State University, Detroit, MI 48202, USA

${ }^{m}$ Institute of Marine Sciences, University of North Carolina at Chapel Hill, Morehead City, NC 28557, USA

*: Corresponding author : Valerie J. Harwood, tel.: +1 8139741524 ; email address : vharwood@usf.edu
}

\begin{abstract}
:
An inter-laboratory study of the accuracy of microbial source tracking (MST) methods was conducted using challenge fecal and sewage samples that were spiked into artificial freshwater and provided as unknowns (blind test samples) to the laboratories. The results of the Source Identification Protocol Project (SIPP) are presented in a series of papers that cover 41 MST methods. This contribution details the results of the virus and bacteriophage methods targeting human fecal or sewage contamination. Human viruses used as source identifiers included adenoviruses (HAdV), enteroviruses (EV), norovirus Groups I and II (NoVI and NoVII), and polyomaviruses (HPyVs). Bacteriophages were also employed, including somatic coliphages and F-specific RNA bacteriophages (FRNAPH) as general indicators of fecal contamination. Bacteriophage methods targeting human fecal sources included genotyping of FRNAPH isolates and plaque formation on bacterial hosts Enterococcus faecium MB-55, Bacteroides HB-73 and Bacteroides GB-124. The use of small sample volumes $(\leq 50 \mathrm{ml})$ resulted in relatively insensitive theoretical limits of detection $(10-50$ gene copies or plaques $\times 50 \mathrm{ml}^{-1}$ ) which, coupled with low virus concentrations in samples, resulted in high false-negative rates, low sensitivity, and low negative predictive values. On the other hand, the specificity of the human virus methods was generally close to $100 \%$ and positive predictive values were $\sim 40-70 \%$ with the exception of NoVs, which were not detected. The bacteriophage methods were generally much less specific toward human sewage than virus methods, although FRNAPH II
\end{abstract}


genotyping was relatively successful, with $18 \%$ sensitivity and $85 \%$ specificity. While the specificity of the human virus methods engenders great confidence in a positive result, better concentration methods and larger sample volumes must be utilized for greater accuracy of negative results, i.e. the prediction that a human contamination source is absent.

\section{Graphical abstract}

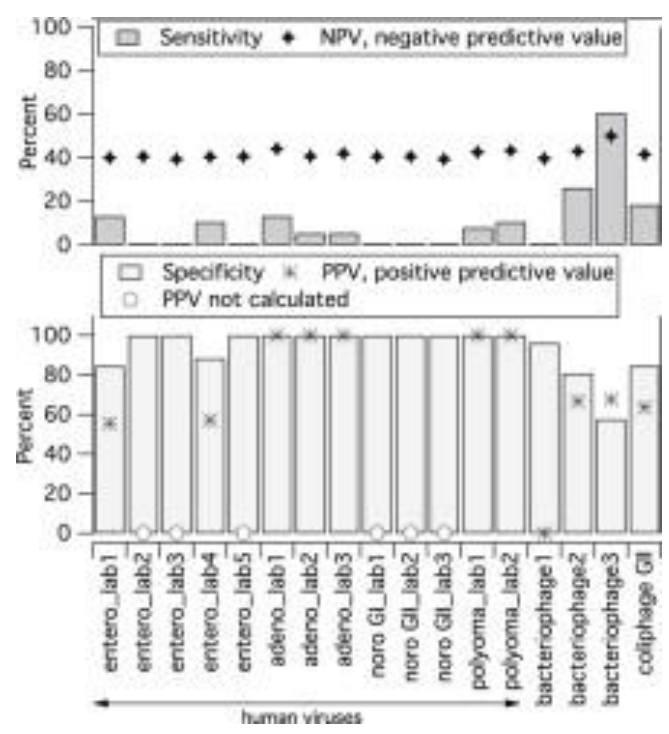

\section{Highlights}

A multi-lab comparison of virus and bacteriophage accuracy toward human feces and sewage. Human viruses were host-specific, but lacked sensitivity and negative predictive value. Bacteriophage methods either lacked sensitivity to human fecal material or were non-specific. Performance of insensitive methods should be improved by larger sample volumes. Use of larger samples requires better concentration methods that do not concentrate inhibitors.

Keywords: Virus ; Bacteriophage ; Water quality ; Fecal pollution ; Validation 
Revised VJH 03/04/13

\section{Introduction}

Coastal waters impacted by fecal contamination pose a health risk to recreational users and shellfish consumers. To identify contaminated waters, fecal indicator bacteria (FIB) such as

59 enterococci are typically monitored. However, analysis for conventional FIB cannot distinguish

60 sources of contamination. The Source Identification Protocol Project (SIPP) was conducted to

61 evaluate methods that may be useful to identify sources of fecal contamination in water. The

62 strategy of the study was to share samples that were intentionally contaminated with fecal

63 material and blinded with respect to source with multiple laboratories to determine if methods

64 under development could correctly identify sources of fecal pollution. This study constitutes the

65 largest multi-laboratory study on microbial source tracking (MST) conducted to date, and

66 provides a rare opportunity to compare the performance of a variety of viral markers for specific

67 contamination sources on a head-to-head basis.

While some studies have shown a positive relationship between FIB levels and

69 gastrointestinal (GI) illness (Wade et al. 2006, Wade et al. 2003, Kay et al. 1994), other studies

70 have found no relationship between FIB and the presence of human pathogens (Boehm et al.

71 2003, Noble and Fuhrman 2001, Jiang and Chu 2004, McQuaig et al. 2012, Jiang et al. 2001) or

72 with GI illness (Colford et al. 2007). Viruses are implicated as important, or even dominant

73 etiological agents of waterborne and shellfish-borne disease (WHO 2003, Westrell et al. 2010),

74 and their fate and transport in aquatic environments may well be very different than that of

75 bacteria. Viruses are therefore increasingly used as MST tools (McQuaig et al. 2012, Noble et

76 al. 2003).

77 The use of viruses for MST has a number of advantages over using bacterial markers.

78 First, measuring pathogenic viruses directly may provide a more accurate measure of GI risk, 
Revised VJH 03/04/13

79 eliminating errors introduced by weak correlations between bacteria and GI illness or viral

80 pathogens. Second, the morphology of many non-pathogenic viruses is similar to that of viral

81 pathogens, and some studies have found that they exhibit similar fate and transport in the

82 environment (Savichtcheva and Okabe 2006). Thus, their decay rate through wastewater

83 treatment and/or in polluted waters may be more similar to viral pathogens than other indicators

84 (Walters et al. 2009), although some studies on drinking water have found that adhesion

85 characteristics (Pelleieux et al. 2012) and removal rates (Boudaud et al. 2012) for bacteriophages

86 MS2, Q $\beta$ and GA differ among these phages. Third, many pathogenic and non-pathogenic

87 viruses are highly host-specific (McQuaig et al. 2012, Noble et al. 2003, Cox et al. 2005,

88 McQuaig et al. 2006, McQuaig et al. 2009), which improves confidence in identification of

89 pollution sources. Virus concentrations in waste can be similar to that of FIB, e.g. human

90 polyomaviruses at $\sim 10^{4} \cdot \mathrm{ml}^{-1}$ in untreated sewage (McQuaig et al. 2009) and human adenoviruses

91 at $\sim 10^{5} \cdot \mathrm{ml}^{-1}$ (Bofill-Mas et al. 2006).

92 A disadvantage of the use of viruses for MST is the relatively low concentrations of some

93 viruses in polluted waters, which can lead to low sensitivity in analysis of environmental samples

94 (Staley et al. 2012, Harwood et al. 2009, Wong et al. 2012). Certain viruses are shed in high

95 numbers in the feces of infected individuals (Melnick and Rennick 1980). However, the number

96 of infected individuals within a population varies depending on the season and etiological agent,

97 as well as the general health of the population. Dilution after waste enters the environment can

98 also lead to low viral concentrations in aquatic environments. This issue is compounded by the

99 methodological challenges encountered in concentrating and enumerating viruses. The basic

100 steps for virological analysis of water include sample concentration, nucleic acid extraction, and

101 molecular detection. These procedures can be expensive, time-consuming, and they often have 
Revised VJH 03/04/13

102 poor to mediocre recovery rates, particularly when viral concentrations are low (McQuaig et al.

103 2009, Wong et al. 2012, Wyn-Jones et al. 2011, Stewart et al. 2008).

104 The pathogenic viruses used in the SIPP study, including adenoviruses, enteroviruses,

105 and noroviruses, were chosen for their association with water-related GI illness, their ability to

106 persist in sewage, sometimes through water treatment processes, and their widespread

107 distribution in human populations. Norovirus is thought to be the dominant etiological agent for

108 GI illness from exposure to recreational waters in developed countries (Soller et al. 2010,

109 Sinclair et al. 2009, Atmar and Estes 2006, Svraka et al. 2007). Studies worldwide have also

110 frequently detected enteroviruses (Noble and Fuhrman 2001, Reynolds et al. 1998, Moce-Llivina

111 et al. 2005, Sassoubre et al. 2012) and adenoviruses in recreational waters (Jiang et al. 2001,

112 Wyn-Jones et al. 2011, Hundesa et al. 2006). Enteroviruses can tolerate a range of temperatures

113 and salinities (Wetz et al. 2004, Skraber et al. 2004) as well as residual chlorine (Keswick et al.

114 1984). Adenoviruses have been found to be more resistant to UV disinfection than other viruses

115 (Thurston-Enriquez et al. 2003).

116 Nonpathogenic human polyomaviruses (BK and JC) and bacteriophages were also used

117 as source-specific or general markers of contamination in the SIPP study. HPyVs are rarely

118 pathogenic and they are prevalent in sewage influent and onsite wastewater disposal system

119 (septic) tanks due to their wide distribution in human populations and excretion in urine and

120 feces (Hundesa et al. 2006, Bofill-Mas et al. 2000, Markowitz et al. 1993, Polo et al. 2004,

121 Vanchiere et al. 2009, Vanchiere et al. 2005). HPyVs have successfully been used as MST tools,

122 and are highly human-specific (McQuaig et al. 2012, McQuaig et al. 2006, McQuaig et al. 2009,

123 Bofill-Mas et al. 2006, Harwood et al. 2009, Gourmelon et al. 2010). Bacteriophages are viruses

124 that infect bacteria, and they have been used for decades as indicators of enteric viruses in 
Revised VJH 03/04/13

125 sewage (reviewed in Chapter 6: Phage Methods (Jofre et al. 2011). Relatively simple and

126 inexpensive culture-based assays for bacteriophage enumeration have been developed as

127 standard methods in the European Union (Anon 2000, 2001). Some bacteriophages, including

128 FRNAPH and Bacteroides phages, can be useful for microbial source tracking of human fecal

129 contamination (reviewed in Chapter 6: Phage Methods (Jofre et al. 2011). FRNAPH, for example

130 are classified into four main genotypes, two of which (II, and III) predominate in wastewater

131 effluents and human fecal samples and two of which (I and IV) are mainly associated with

132 animal feces and effluents from animal-rearing facilities or slaughterhouses (Gourmelon et al.

1332010 , Hsu et al. 1995).

134 This paper focuses on the performance of the viral markers measured during the SIPP

135 study. Water samples contaminated with single-source or mixed-source fecal material were

136 evaluated by laboratories which volunteered for the study, and which were already using the

137 methods. No effort was made to harmonize virus enumeration methodologies across

138 participating laboratories, as a major goal of the study was to incorporate variation at the

139 laboratory scale into viral marker performance. Due to logistical limitations of the very large

140 study, sample sizes were standardized across bacterial and viral methods (Boehm et al. 2013).

141 Crucial performance characteristics including specificity, sensitivity and detection limits

142 (Stoeckel and Harwood 2007) of viral markers were compared to help identify methods with the

143 most promise for identifying sources of fecal waste in water. These results are intended to help

144 provide the best tools to water resource managers and policy makers who work to protect public

145 health in coastal areas.

\section{2. Materials and Methods}

147 2.1. Participants 
Revised VJH 03/04/13

The methods are organized by participating laboratories. The institutions, locations, and abbreviations used are given below, and the method(s) performed by each laboratory are

provided in Table 1. The laboratories involved in this study were: Institut Français de Recherche

151 pour l'Exploitation de la Mer (IFREMER), France; Federal Office of Public Health (FOPH),

152 Switzerland; Southern California Coastal Water Research Project (SCCWRP), USA ; Stanford

153 University (Stanford), USA; TetraTech, USA; University of Brighton (UB), United Kingdom;

154 University of North Carolina Chapel Hill (UNC-CH), USA; University of North Carolina Chapel

155 Hill Institute of Maine Science (UNC-CH-IMS), USA; University of South Florida (USF), USA;

156 University of Southern California (USC), USA; Wayne State University (WSU), USA.

\subsection{Sample handling, concentration, and nucleic acid extraction}

158 All collection and preparation of fecal ("challenge") samples were carried out by the

159 Southern California Coastal Water Research Project (SCCWRP) in Costa Mesa, CA. Sample

160 collection, preparation, and shipping procedures are detailed in a companion paper that provides

161 an overview of the entire inter-laboratory study (Boehm et al. 2013). Briefly, artificial freshwater

162 (distilled water with $0.3 \mathrm{mM} \mathrm{MgCl}_{2}, 0.6 \mathrm{mM} \mathrm{CaCl}_{2}$, and $1.4 \mathrm{mM} \mathrm{NaHCO}_{3}$ (Boehm et al. 2013))

163 was intentionally contaminated with fecal and/or sewage samples from various sources. All fecal

164 samples were composites from at least twelve individuals. Nineteen "singleton" samples were

165 inoculated with one fecal source (chicken, deer, dog, goose, gull, horse, pig, pigeon, cow, human

166 feces, septage or sewage), and 13 doubleton samples were inoculated with two fecal sources each

167 at volumetric ratios of 9:1. Six of the singleton samples contained human fecal material. Seven

168 of the singleton samples were created at both full strength and at 1:10 diluted strength. All of the

169 doubleton samples contained a human source. A full list of the samples can be found in Table 2

170 of Boehm et al. (2012). Duplicates of each sample were processed as described below so that 
Revised VJH 03/04/13

171 each participating lab received 64 filters or liquid samples for processing with their method. All

172 filters (see below for method details) were frozen in liquid nitrogen and shipped on dry ice, while

173 liquid samples for bacteriophages were shipped on blue ice. Procedures are organized below by

174 participating laboratory. Viral targets used in the study, laboratories, primers, probes and

175 citations for methods are presented in Table 1. Enterococci (ENT) concentrations were also

176 measured using membrane filtration in each sample by USEPA Method 1600 (USEPA 2002),

177 with method details reported elsewhere (Boehm et al. 2013).

178 SCCWRP. Human enteroviruses (EV) were enumerated in $50 \mathrm{ml}$ challenge samples filtered

179 through $0.45 \mu \mathrm{m}$ mixed cellulose filters (Millipore, MA). Replicate volumes of each sample were

180 acidified with $10 \% \mathrm{HCl}$ until a $\mathrm{pH}$ of 3.5 was reached and then filtered as before. Filters were

181 stored at $-80{ }^{\circ} \mathrm{C}$ until extraction. Viral nucleic acids were extracted using the QIAamp MinElute

182 Virus Spin Kit (Qiagen, Valencia, CA). The extraction was performed according to manufacturer

183 instructions and $40 \mu \mathrm{l}$ was eluted. One unamended filter and one acidified filter were extracted

184 for each sample. Nucleic acid extracts were stored at $-80{ }^{\circ} \mathrm{C}$ until analysis.

185 Stanford. Human enteroviruses (EV), adenoviruses (HAdV), and norovirus II (NoV GII)

186 were enumerated in $50 \mathrm{ml}$ challenge samples filtered through $0.45 \mu \mathrm{m}$ mixed cellulose filters

187 (Millipore, $\mathrm{MA})$. Magnesium chloride $\left(\mathrm{MgCl}_{2}\right)$ was added to samples before membrane filtration

188 to increase viral recover by facilitating virus attachment to the filters (Mendez et al. 2004).

189 Briefly, $1 \mathrm{ml}$ of $5 \mathrm{M} \mathrm{MgCl}_{2}$ was added to $50 \mathrm{ml}$ of sample for a final concentration of $0.1 \mathrm{M}$

$190 \mathrm{MgCl}_{2}$ before membrane filtration. Filters were stored at $-80{ }^{\circ} \mathrm{C}$ until extraction. Viral nucleic

191 acids were extracted using the QIAamp MinElute Virus Spin Kit (Qiagen, Valencia, CA)

192 according to manufacturer instructions and $40 \mu \mathrm{l}$ was eluted. For each sample, nucleic acids 
Revised VJH 03/04/13

193 were extracted from two filters and the eluants combined to provide enough volume for all the

194 viral assays being run. Nucleic acid extracts were stored at $-80{ }^{\circ} \mathrm{C}$ until analysis.

195 Tetra Tech. Human polyomaviruses (HPvYs) and HAdV were concentrated according to a 196 previously published protocol (Katayama et al. 2002). Samples were acidified to $\mathrm{pH} 3.5$ with

$197 \mathrm{HCl}$ and were then filtered through type HA, negatively charged membranes (Millipore,

198 Billerica, Mass.) with a $47 \mathrm{~mm}$ diameter and a $0.45 \mu \mathrm{m}$ pore size. Filters were stored in $1.5-\mathrm{ml}$ 199 microcentrifuge tubes and shipped on ice to analytical laboratory. At the analytical laboratory, 200 filters were stored at $-80^{\circ} \mathrm{C}$ prior to further processing. Viral nucleic acid was extracted and 201 purified using Qiagen QIAamp MinElute Virus Spin Kit (Qiagen, Valencia, CA) following the 202 manufacturer's protocol with minor modifications. Upon removal from the freezer, $400 \mu 1$ of 203 RNAse free water was added into each tube with filter and pulse-vortex for $30 \mathrm{~s}$ to release viral 204 particles from the filters. Purification steps were then performed according to manufacturer's 205 protocol. Purified viral RNA/DNA was eluted in $100 \mu \mathrm{l}$ of RNase-free water and stored at $-20^{\circ} \mathrm{C}$.

206 UNC-CH. Human enteroviruses (EV), human norovirus I (NoV GI) and norovirus II

207 (NoV GII) were enumerated in $50 \mathrm{ml}$ challenge samples filtered through $0.45 \mu \mathrm{m}$ mixed

208 cellulose filters (Millipore, MA). Filters were stored at $-80{ }^{\circ} \mathrm{C}$ until extraction. Viral nucleic

209 acids were extracted using a modified version of the RNeasy Mini Kit (Qiagen, Valencia, CA) as

210 described previously (Gregory et al. 2006). Nucleic acid extracts were eluted into $30 \mu 1$ of

211 DNase- and RNase-free water and stored at $-80{ }^{\circ} \mathrm{C}$ until analysis.

212 UNC-CH-IMS. Human adenoviruses (HAdV) were enumerated in $50 \mathrm{ml}$ challenge 213 samples filtered through $47 \mathrm{~mm}$ HA filters with a pore size of $0.45 \mu \mathrm{m}$. Filters were stored at $21480^{\circ} \mathrm{C}$ until further processing. Frozen filters were transferred to $2 \mathrm{~mL}$ semi-conical screw-cap 215 tubes loaded with $0.3 \mathrm{~g}$ of $0.1 \mathrm{~mm}$ glass beads (BioSpec, Bartlesville, OK) and $990 \mu \mathrm{L}$ of AE 
Revised VJH 03/04/13

216 Buffer (Qiagen, Valencia, CA). Tubes were bead beaten for 2 min at maximum speed and

217 centrifuged for $1 \mathrm{~min}$ at $12,000 \mathrm{x} \mathrm{g}$. Supernatant were transferred to $1.7 \mathrm{~mL}$ microtubes and

218 centrifuged again for $5 \mathrm{~min}$ at $12,000 \mathrm{x}$ g. Supernatant was transferred carefully to new $1.7 \mathrm{~mL}$

219 microtubes, and DNA was extracted using DNA-EZ RW01 kits (GeneRite, New Brunswick, NJ)

220 following manufacturer instructions.

221 USC. Human enteroviruses (EV) were enumerated in $50 \mathrm{ml}$ challenge samples filtered

222 through $47 \mathrm{~mm}$ nitrocellulose filters with a pore size of $0.45 \mu \mathrm{m}$ (Millipore, MA). RNA was

223 extracted from filters using the RNeasy Mini Kit (Qiagen, Valencia, CA) according to

224 manufacturer instructions with modifications as specified in (Fuhrman et al. 2005).

225 USF. Human polyomaviruses BK and JC (HPyV) were enumerated in $50 \mathrm{ml}$ challenge

226 samples filtered through $47 \mathrm{~mm}$ nitrocellulose filters, pore size $0.45 \mu \mathrm{m}$, after sample $\mathrm{pH}$ was

227 adjusted to 3.5 using $2.0 \mathrm{~N} \mathrm{HCl}$ (McQuaig et al. 2009). Filters were immediately frozen at $-80^{\circ} \mathrm{C}$

228 until they were analyzed (within 30 days of receipt). DNA was extracted from filters by

229 mechanical disruption (bead beating) using GeneRite bead tubes (North Brunswick, NJ).

230 Bacteriophage Analysis (IFREMER. FOPH, UB, WSU). Laboratories received $50 \mathrm{ml}$ of

231 each raw (unfiltered) challenge sample. Samples were shipped on blue ice. One to $5 \mathrm{ml}$ of

232 sample was added to a suspension of the appropriate host for enumeration of Bacteroides phages,

233 somatic coliphages, FRNAPH and Enterococcus phages (see Section 2.3). FRNAPH genotyping

234 was carried out on isolated plaques obtained using a previously published protocol (Mauffret et

235 al. 2012).

236

237

\subsection{Analytical methods}


Revised VJH 03/04/13

Challenge samples were tested for inhibition of qPCR reactions prior to shipment from

239 SCCWRP to the individual laboratories (see (Boehm et al. 2013) for details). Individual

240 laboratories also tested for inhibition using qualitative methods such as running conventional

241 PCR for 16S rRNA or general Bacteroidales on the sample, semi-quantitative methods such as

242 diluting samples 1:5 or 1:10 and comparing $\mathrm{C}_{\mathrm{T}}$ values to those obtained for undiluted samples

243 (Cao et al. 2012), or quantitative methods using a commercially-supplied internal control

244 (QuantiFast Pathogen +IC Kit, Qiagen) (data not shown). Few instances of inhibition were noted

245 by any of the laboratories and when they were, samples were diluted 1:5 or 1:10 and re-analyzed.

246 SCCWRP. EV were enumerated by reverse transcription-QPCR (RT-QPCR) on a

247 BioRad CFX 96 thermocycler using TaqMan ${ }^{\circledR}$ RNA-to-Ct ${ }^{\mathrm{TM}}$ 1-Step Kit (Applied Biosystems,

248 CA) using the protocols cited (Walters et al. 2009, Gregory et al. 2006, De Leon et al. 1990).

249 Cycling parameters included a $15 \mathrm{~min}$ RT step at $48^{\circ} \mathrm{C}$, followed by a 10 min denaturation step

250 at $95{ }^{\circ} \mathrm{C}$ and then 40 cycles of $95^{\circ} \mathrm{C}$ for $15 \mathrm{~s}$ and $60^{\circ} \mathrm{C}$ for $60 \mathrm{~s}$. Fluorescence data were

251 analyzed using BioRad CFX96 software v2.0 with a threshold fluorescence value of 100. RNA

252 standards were made by in vitro transcription of plasmids extracted from an E. coli clone.

253 Standards were quantified using a Nanodrop-1000 (Thermo Scientific, Wilmington, DE) and

254 serially diluted to make standard curves. The highest concentration of enterovirus standard was

$2551.5^{*} 10^{6} \mathrm{PFU} / \mathrm{ml}$. Standard curves were run in triplicate on every qPCR plate containing samples.

256 All enterovirus standard curves were 'pooled' and the 'pooled' standard curves were then used to

257 relate quantification cycles $\left(\mathrm{C}_{\mathrm{q}}\right)$ to copy numbers and quantify samples (Sivaganesan et al. 2010).

258 Stanford. HAdV were enumerated by QPCR on an Applied Biosystems StepOnePlus

259 real-time PCR system using TaqMan chemistry (Jothikumar et al. 2005). Each sample was run in

260 triplicate. Thermocycling parameters included $95{ }^{\circ} \mathrm{C}$ for $10 \mathrm{~min}$ followed by 45 cycles of $95{ }^{\circ} \mathrm{C}$ 
Revised VJH 03/04/13

261 for $15 \mathrm{~s}$ and $55^{\circ} \mathrm{C}$ for $1 \mathrm{~min}$. Fluorescence data were analyzed using Applied Biosystems

262 StepOnePlus software v2.0 with a threshold of 0.03. Standard curves were generated from E. coli

263 plasmid DNA and run in triplicate with every set of samples, and then pooled by the same

264 method as the SCCWRP protocol described above.

265 EV were enumerated by reverse transcription-QPCR (RT-QPCR) on an Applied

266 Biosystems StepOnePlus thermocycler using TaqMan® RNA-to-Ct ${ }^{\text {TM }}$ 1-Step Kit (Applied

267 Biosystems, CA) using previously published protocols (Walters et al. 2009, Gregory et al. 2006,

268 De Leon et al. 1990). Samples were run in triplicate. Cycling parameters included a 15 min RT

269 step at $48{ }^{\circ} \mathrm{C}$, followed by a 10 min denaturation step at $95{ }^{\circ} \mathrm{C}$ and then 45 cycles of $95{ }^{\circ} \mathrm{C}$ for 15

$270 \mathrm{~s}$ and $60{ }^{\circ} \mathrm{C}$ for $60 \mathrm{~s}$. Fluorescence data were analyzed using Applied Biosystems StepOnePlus

271 software v2.0 with a threshold of 0.03 . RNA standards were made by in vitro transcription of

272 plasmids extracted from an E. coli clone. Standards were quantified using a Nanodrop-1000

273 (Thermo Scientific, Wilmington, DE) and serially diluted to make standard curves. Standard

274 curves were run in triplicate with every set of samples and then pooled.

275

NoV GII were enumerated by reverse transcription-QPCR (RT-QPCR) on an Applied

276 Biosystems StepOnePlus thermocycler using TaqMan® RNA-to-Ct ${ }^{\text {TM }}$ 1-Step Kit (Applied

277 Biosystems, CA), according to previously described methods (da Silva et al. 2007, Jothikumar et

278 al. 2005b, Kageyama et al. 2003). Samples were run in triplicate. Cycling parameters included a

$27915 \mathrm{~min}$ RT step at $48{ }^{\circ} \mathrm{C}$, followed by a 10 min denaturation step at $95{ }^{\circ} \mathrm{C}$ and then 45 cycles of

$28095^{\circ} \mathrm{C}$ for $15 \mathrm{~s}$ and $60{ }^{\circ} \mathrm{C}$ for $60 \mathrm{~s}$. Fluorescence data were analyzed with a threshold of 0.005 .

281 RNA standards were made by in vitro transcription of plasmids extracted from an E. coli clone.

282 Standards were quantified using a Nanodrop-1000 (Thermo Scientific, Wilmington, DE) and

283 serially diluted to make standard curves. Standard curves were run in triplicate with every set of 
Revised VJH 03/04/13

284

285

286

287

288

289

290

291

292

293

294

295

296

297

298 299 reaction.

300

301

302

303

304

305

306

samples, and then pooled.

Tetra Tech. HPyV and HAdV analyses were performed by QPCR using the Quantifast Pathogen PCR + IC kits (Qiagen, Valencia,CA) following the manufacturer's suggestion for PCR cycling conditions. Primers and probes sequences for each target organisms were adapted from the literature (Table 1). The Quantifast Pathogen PCR kit was supplemented with an Internal Control DNA and a standardized Internal Control assay. The presence of PCR inhibitor in the samples was determined by the deviation of \pm 3 threshold cycles of mean $\mathrm{Ct}$ value of the internal control. Samples that showed PCR inhibition were diluted and reanalyzed. Non-linearized plasmids with target DNA inserts (DNA2.0, Menlo Park, CA) were used as DNA standards for all target organisms. Concentration of each DNA standard was measured with a NanoDrop 2000 spectrophotometer (Thermo Scientific, Wilmington, DE). DNA standards were serially diluted to obtain standard curves. All real-time PCR reactions were performed on RotorGene Q (Qiagen, Valencia, CA). Sensitivities of these assays range between $10^{1}$ to $10^{2}$ plasmid copies per PCR reaction. PCR analyses of all samples were performed in duplicate. All qPCR runs included at least one negative control reaction (PCR-grade $\mathrm{H}_{2} \mathrm{O}$ without template) and a positive control

UNC-CH. EV was detected by reverse transcription-PCR (RT-PCR) on a Cepheid SmartCycler thermocycler using a Quantitect Probe RT-PCR kit (Qiagen) using previously published primers and probes (Donaldson et al. 2002). The RT-PCR reaction mixture contained $2 \mu \mathrm{l}$ of sample, each primer at a concentration of $500 \mathrm{nM}$, each probe mixture at a concentration of $120 \mathrm{nM}, 12.5 \mu \mathrm{l}$ of $2 \mathrm{X}$ RT-PCR buffer, $0.3 \mu \mathrm{l}$ of $25 \mathrm{X}$ RT-PCR enzyme mix, and nuclease-free water for a total reaction mixture of $25 \mu \mathrm{L}$. The reaction mixture was subjected to a one-step assay on using the following conditions: (i) RT for $30 \mathrm{~min}$ at $50^{\circ} \mathrm{C}$, (ii) $15 \mathrm{~min}$ at $95^{\circ} \mathrm{C}$, (iii) 45 
Revised VJH 03/04/13

cycles of $15 \mathrm{~s}$ at $94^{\circ} \mathrm{C}$ and $1 \mathrm{~min}$ at $60^{\circ} \mathrm{C}$. All amplification reactions were carried out in

duplicate. Fluorescence data was analyzed using Cepheid SmartCycler software with a threshold of 30. All amplification reactions were carried out in duplicate. Samples that gave a positive result in either or both of the duplicate reactions were amplified by RT-PCR again. Only after a

311 sample gave a second positive result was it counted as an overall positive.

NoV GI and GII were enumerated by reverse transcription-QPCR (RT-QPCR) on a

313 Cepheid SmartCyler using a Quantitect Probe RT-PCR kit using previously published primers

314 and probes (Jothikumar et al. 2005b). The RT-PCR reaction mixture was the same as for EV run

315 by this lab. The reaction mixture was subjected to a one-step assay using the following

316 conditions: (i) RT for $30 \mathrm{~min}$ at $50^{\circ} \mathrm{C}$, (ii) $15 \mathrm{~min}$ at $95^{\circ} \mathrm{C}$, (iii) 45 cycles of $15 \mathrm{~s}$ at $94^{\circ} \mathrm{C}$ and 1

$317 \min$ at $60^{\circ} \mathrm{C}$. All amplification reactions were carried out in duplicate. Fluorescence data was 318 analyzed using Cepheid SmartCycler software with a threshold of 30. RNA standards were a 319 NoV GI.4 RNA transcript and a NoV GII.1 RNA transcript (courtesy J. Vinjé, CDC) that were 320 serially diluted to make standard curves.

321 USC. EV were enumerated by reverse transcription-QPCR (RT-QPCR) on a Stratagene

322 MX3000, by a modification of the 2-step protocol from Monpoeho et al. (2001) as described by 323 Fuhrman et al. (2005).

324 UNC-CH-IMS. HAdV were detected using a conventional PCR assay targeting the hexon 325 gene (Xu et al. 2001). Each sample was run in duplicate. Each $50 \mu \mathrm{L}$ reaction contained $5 \mu \mathrm{L}$ of 326 sample DNA extract, each primer at a concentration of $0.2 \mu \mathrm{M}, 50 \mathrm{mM} \mathrm{MgSO}, 0.2 \mathrm{mM}$ (each) 327 dNTP, and one unit of Platinum Taq HiFi (Invitrogen, Grand Island, NY). Reactions were 328 thermal cycled on a MyCycler (BioRad, Hercules, CA) in two stages: (i) $94^{\circ} \mathrm{C}$ for 2 min, and (ii) 32935 cycles of $94^{\circ} \mathrm{C}$ for $30 \mathrm{~s}, 55^{\circ} \mathrm{C}$ for $30 \mathrm{~s}$, and $68^{\circ} \mathrm{C}$ for $1 \mathrm{~min}$. PCR products were visualized on 
Revised VJH 03/04/13

330 a 1.0\% agarose gel stained with ethidium bromide and visualized on a GelDoc imaging system

331 (BioRad, Hercules, CA).

332 Bacteriophage Analysis (IFREMER. FOPH, UB, WSU). Enumeration of somatic

333 coliphages was carried in accordance with standard methods (Anon 2000) using the host strain $E$.

334 coli WG-5, and was based on a double agar plaque count procedure similar to that described

335 below for Bacteroides phage detection (Anon 2001). Screw-topped glass tubes (Hach, UK)

336 containing BPRM broth were used to grow strain GB-124 (1 ml host in $12 \mathrm{ml}$ broth) to the

337 correct optical density (approx. 0.33 at $620 \mathrm{~nm}$ ) for phage detection. Once the correct optical

338 density was reached (usually within $3 \mathrm{~h}$ ), strain GB-124 was placed on melting ice and used

339 within 4 h. All samples were filtered using $0.22 \mathrm{~mm}$ polyvinylidene difluoride (PVDF) membrane

340 syringe filters (Millipore, US) to remove any background bacterial contamination before phage

341 detection. On each occasion, $1 \mathrm{ml}$ of the filtrate (or dilution thereof) and $1 \mathrm{ml}$ of host GB-124

342 were added to a sterile $10 \mathrm{ml}$ disposable test tube containing $2.5 \mathrm{ml}$ of semi-solid BPRM agar

343 (Ebdon et al. 2007); log phase Bacteroides strains (GB-124, GA-17) and Enterococcus faecium

344 strains (HB-73, and MB-55) (1 mL) and $5 \mathrm{~mL}$ of sample filtrate were added to $4 \mathrm{~mL}$ of $2 \mathrm{X}$

345 BPRM agar (Vijayavel et al. 2010) and mixed gently to avoid bubble formation. The contents

346 were then poured onto the surface of BPRM agar and left to solidify. The plates were inverted

347 and incubated at $36^{\circ} \mathrm{C}\left( \pm 2{ }^{\circ} \mathrm{C}\right)$ for $18( \pm 2) \mathrm{h}$ in anaerobic jars containing anaerobic sachets

348 (Anaerogen, Oxoid, UK). The presence of phages resulted in the production of visible plaques

349 (zones of lysis) in a confluent lawn of the host bacterium. All samples were analyzed in at least

350 duplicate and expressed as the mean number of plaque forming units (PFU) $\cdot 100 \mathrm{ml}^{-1}$.

351 FRNAPH were counted according to the ISO 10705-1 method by analyzing $2 \mathrm{~mL}$ of each

352 sampleusing the host strain Salmonella enterica Typhimurium WG-49. In addition, for samples 
Revised VJH 03/04/13

353 with low virus levels, a concentration step was performed on the remaining $48 \mathrm{~mL}$ of sample by

354 flocculation with $\mathrm{MgCl}_{2}(0.05 \mathrm{M})$ followed by filtration through $0.22 \mu \mathrm{m}$ filters (GSWP047S0,

355 Millipore, St Quentin en Yvelines, France). The viruses on the filter were then recovered in $5 \mathrm{~mL}$

356 eluent (Gourmelon et al. 2007) and analyzed as described above, however, bacteriophage

357 isolated following the secondary concentration step were not used in the estimation of

358 concentration, but were used for typing. Plaques were individually picked and stored in $15 \%$

359 PBS-glycerol at $-20^{\circ} \mathrm{C}$ until genotyping. Isolates were cultivated on Petri dishes with or without

360 RNase. Isolates that were not sensitive to this treatment corresponded to DNA bacteriophages

361 and were removed from the analysis. FRNAPH were genotyped using a QuantiTech probe RT-

362 PCR kit (Qiagen, France) and previously published primers (Ogorzaly and Gantzer 2006). When

363 less than five plaques could be isolated for typing, the result was reported as "non-conclusive."

\section{$364 \quad$ 2.3. Data reporting}

365 All data were reported by the participating laboratories on a common spreadsheet. The units for

366 QPCR methods were gene copies $\cdot$ filter $^{-1}$ and those for bacteriophage methods were plaque

367 forming units $(\mathrm{PFU}) \cdot 50 \mathrm{~mL}^{-1}$. The theoretical limit of detection $\left(\mathrm{LOD}_{\mathrm{T}}\right)$ was calculated by

368 assuming that 1 gene copy or PFU could be detected in a given test (PCR reaction or plate), and

369 subsequently calculating the minimum quantity that must be present on a filter (or in $50 \mathrm{~mL}$ ) of

370 sample to be detected given the concentration factor through processing and the volume used in

371 each method. The $\mathrm{LOD}_{\mathrm{T}}$ calculation also assumes $100 \%$ recovery through processing, and is

372 therefore an optimistic estimate of the LOD. Results for samples in which target was detected,

373 but reported by the participating laboratories at levels below the $\mathrm{LOD}_{\mathrm{T}}$ were considered positive,

374 but were not quantified. Conventional (binary) PCR methods were reported as +/- results.

\section{2.4. Statistical analysis}


Revised VJH 03/04/13

376 All virus and bacteriophage data sets were translated into binary data indicating presence or

377 absence. The FRNAPH typing data was translated into a binary data set indicating the presence

378 or absence of human feces (i.e., genotype II): if the typing indicated human was present (either

379 alone or with animals), then it was considered positive for human feces; if the typing was

380 inconclusive (less than five plaques available for typing), or if no plaques were present, it was

381 considered negative for human feces. Statistical analyses were carried out using SPSS Statistics

382 version 20.0.0 (IBM, Foster City, CA, USA). The agreement between the binary data sets was

383 determined using the phi coefficient. A one-way ANOVA was used to assess whether somatic

384 coliphage and enterococci concentrations were significantly higher when either individual human

385 viruses, human-associated bacteriophages, or FRNAPH were present. Somatic coliphage and

386 enterococci concentrations were $\log _{10}$ - transformed for statistical analysis. Statistical significance

387 was determined at $\alpha=0.05$.

388 The sensitivity, specificity, positive predictive value, and negative predictive value were

389 calculated for each assay using Matlab version 2009b (Natick, MA). The formulas for these

390 metrics are provided below, where true positive is abbreviated TP, false positive is $\mathrm{FP}$, true

391 negative in $\mathrm{TN}$, and false negative is $\mathrm{FN}$, and all are expressed as percentages. Sensitivity, or the

392 ability of the test to detect a contamination source when it is present, was calculated as

393 sensitivity $=\mathrm{TP} /(\mathrm{TP}+\mathrm{FN})$. Specificity, or the ability of a test to detect only the target

394 contaminant source and no other, was calculated as specificity $=\mathrm{TN} /(\mathrm{FP}+\mathrm{TN})$. Positive

395 predictive value, or the frequency at which a positive test result is a true positive, was calculated

396 as $\mathrm{PPV}=\mathrm{TP} /(\mathrm{TP}+\mathrm{FP})$. Negative predictive value, or the frequency at which a negative test result

397 is a true negative, was calculated as NPV $=\mathrm{TN} /(\mathrm{TN}+\mathrm{FN})$. Variables were treated as binary

398 observations ( + or -$)$ for all of these calculations. 
Revised VJH 03/04/13

\section{Results}

Relatively small volumes were used in the PCR and bacteriophage assays; therefore the theoretical limits of detection $\left(\mathrm{LOD}_{\mathrm{T}}\right)$ were relatively insensitive, ranging from 10 - 50 gene copies $\cdot$ filter ${ }^{-1}$ or plaques $50 \mathrm{ml}^{-1}$. The sensitivity and NPV of the virus methods toward challenge samples containing target fecal material tended to be rather low, while specificity and PPV was generally much higher (Tables 2 and 3). Table 2 shows performance measures for the dataset that includes all challenge samples, including singletons and doubletons $(n=64)$, and Table 3 contains the results for the dataset that includes only singleton challenge samples $(n=38)$.

The human viruses were generally highly specific toward human fecal sources (Tables 2 and 3), ranging from $84.6 \%$ to $100 \%$ when considering the dataset containing all samples (Table 2). Cross-reactivity of the assays was observed for two of the EV methods (USC and SCCWRP) toward pig feces, and lowered both specificity and PPV compared to the other human virus methods. In fact, USC and SCCWRP both detected EV in three samples contaminated with pig feces and in all four sewage/pig doubleton samples, while the other two laboratories did not detect EV in these samples. The incomplete specificity of the two EV assays was still evident when considering results from only singleton challenge samples (Table 3); however, only pig fecal sources produced false-positive results.

None of the human virus methods displayed good sensitivity toward human fecal sources (Tables 2 and 3); however, each of the methods except NoVI and NoVII detected the target in at least two samples containing human fecal sources. The method with the best combination of sensitivity and specificity was HAdV (TetraTech), which detected human fecal contamination in five samples (13.2\% sensitivity) in the complete dataset and was $100 \%$ specific (Table 2 ). Results for the singleton dataset (Table 3) were characterized by higher NPVs (mean 68.6\% for 
Revised VJH 03/04/13

422 all human viruses) compared to the complete dataset (mean $41.1 \%$ ) due to the lower frequency of

423 false-negative results in the singleton samples compared to the doubletons. The majority of

424 human virus detections were in sewage samples (76\%), followed by septage (16\%), and lastly

425 human feces $(8 \%)$.

426 The somatic coliphage and FRNAPH methods are general indicators of fecal pollution,

427 rather than source-specific markers. The performance measures shown in Tables 2 and 3 for

428 these coliphages were calculated with respect to human fecal source. Somatic coliphages were

429 present in most of the samples containing human fecal material ( sensitivity $=71 \%$ ), while

430 FRNAPH were present in only $21 \%$ (Table 2 ). Note that the sensitivity of somatic coliphages

431 and FRNAPH toward human fecal material decreased greatly in singleton samples $(8.3 \%$, Table

432 3). The human-associated bacteriophage method with the greatest sensitivity toward samples

433 containing human waste in the complete dataset was the GB-124 bacteriophage assay (60.5\%);

434 however, this method also had low specificity and NPV, indicating a high proportion ( $>50 \%)$ of

435 false-positive results (Table 2). GB-124 cross-reacted with all non-human fecal sources except

436 deer and goose. GB-124 levels in singleton samples from both human-derived and animal fecal

437 samples ranged from undetectable to $700 \mathrm{PFU} \cdot 100 \mathrm{ml}^{-1}$.

438 The human-associated bacteriophage methods HB-73 and FRNAPH II genotyping were more

439 specific than GB-124 (80.8\% and 84.6\%, respectively for the complete dataset), but were not

440 very sensitive toward human fecal sources $(\sim 25 \%)$, and were not as specific as most of the

441 human virus methods. HB-73 cross-reacted with dog, goose, gull, horse, and pigeon feces, while

442 the FRNAPH typing method identified human-associated genotype II phages in gull and pigeon

443 feces. MB-55 was detected in only one sample, which contained cow feces. 
Revised VJH 03/04/13

444

445

446

447

448

449

450

451

452

453

454

455

456

457

458

459

460

461

462

463

464

465

466

Although quantitative methods such as qPCR or plaque counting were used for most of the methods (Table 1), the usefulness of the quantitative data is limited by the low frequency of detection of the viruses. Gene copies filter ${ }^{-1}$ (50 mL of sample was applied to each filter) and fecal source are shown in Table 4 for samples in which the target was reported at concentrations above the $\operatorname{LOD}_{\mathrm{T}}$. Most of the quantities detected were on the order of $10^{2}$ gene copies $\cdot$ filter ${ }^{-1}$, with the exception of EV_USC, which was on average $6.8^{*} 10^{5}$ gene copies $\cdot$ filter ${ }^{-1}$ when detected in samples from human fecal sources (Table 4); however, this method lacked specificity, making the quantitative data unreliable.

Agreement of results among laboratories for viruses that were measured by more than one laboratory was assessed by correlation. Results indicating the presence/absence of target in the 64 challenge samples were positively associated in some instances, e.g. EV results from SCCWRP and USC (phi coefficient $=0.87, \mathrm{p}<0.05$ ). HAdV run by UNC-CH-IMS was also positively associated with EV run by USC and by SCCWRP (phi coefficient $=0.44$ and 0.51 , respectively, $\mathrm{p}<0.05$ for both). HAdV measured by Stanford and TetraTech were positively associated (phi coefficient $=0.28, \mathrm{p}<0.05$ ), but there was no agreement with HAdV data from UNC-CH-IMS. Results from the HB-73 bacteriophage were positively associated with HAdV results from TetraTech ( $p$ hi coefficient $=0.25, \mathrm{p}>0.05$ ), but the human-associated bacteriophage results were not correlated with each other. Results from the two labs that ran HPyV were not correlated, however, the results for HPyV from USF were positively correlated with the results from the three labs running human adenovirus (phi coefficient $=0.41,0.32,0.32$ for HAdV measured by TetraTech, Stanford, and UNC-CH-IMS, respectively, $\mathrm{p}<0.05$ ).

Levels of enterococci and somatic coliphages, both of which are general indicators of fecal contamination, are graphed in Figure 1 along with instances of detection of human viruses and 
Revised VJH 03/04/13

467 human-associated bacteriophages in challenge samples. Enterococci concentrations tended to be

468 higher in the fecal samples compared to the sewage and septage samples, and were particularly

469 high in dog and pigeon fecal samples $\left(\sim 10^{6} \mathrm{CFU} \cdot\right.$ filter $\left.^{-1}\right)$. The relationship between enterococci

470 concentrations and virus detection was determined using ANOVA, in which virus presence or

471 absence was used as a treatment. Several of the methods showed a relationship with enterococci

472 concentrations, i.e. EV_USC detections were associated with lower enterococci levels $\left(\log _{10} 2.69\right.$

473 when EV detected vs. $\log _{10} 3.96$ when EV not detected; $\left.P=0.002\right)$. A similar relationship was

474 found for EV_SCCWRP ( $\log _{10} 2.81$ when EV detected vs. $\log _{10} 3.90$ when EV not detected; $P=$

475 0.019). In contrast, when FRNAPH typing indicated the presence of a human fecal source,

476 somatic coliphage and enterococci concentrations were both significantly higher $(P<0.001$ and

$477 P=0.004$, respectively). FRNAPH detection was associated with significantly higher enterococci

478 levels $\left(\log _{10} 4.40\right.$ when FRNAPH detected vs. $\log _{10} 3.58$ when FRHAPH not detected; $P=$

$4790.015)$.

480 4. Discussion

If MST methods are to be useful in a regulatory and/or management context, one must

482 have good confidence in the performance of the method(s), e.g. that a positive or a negative

483 result is a reliable predictor, at a minimum, of the presence/absence of the targeted source of

484 fecal contamination. The proliferation of MST methods over the last decade has produced a

485 potpourri of possible assays for fecal source identification whose performance is rarely directly

486 compared. This study provided the opportunity for direct comparison; however, because of the

487 many methods and laboratories involved, compromises in sample composition and processing

488 had to be made that were not optimal approaches for some methods. The virus methods, in

489 particular, suffered in terms of sensitivity from the relatively small sample size utilized, although 
Revised VJH 03/04/13

490 these manufactured samples carried quite a high level of contamination as measured by

491 conventional FIB (median enterococci level of 6 X $10^{3} \mathrm{CFU} \cdot$ filter $^{-1}$ ) (Boehm et al. 2013).

492 Membrane filtration of water samples does not always result in good recovery of viruses;

493 however, McQuaig et al. (2012) demonstrated an average efficiency of $90.9 \%$ recovery for

494 HPyVs with the methods utilized here. Furthermore, some viral targets such as HPyVs are shed

495 in urine (McQuaig et al. 2009, Bialasiewicz et al. 2009) and in feces (Vanchiere et al. 2009,

496 Vanchiere et al. 2005, Bialasiewicz et al. 2009), therefore sewage rather than feces is probably a

497 more appropriate source of reference material for such viruses. Larger sample sizes and more

498 efficient concentration methods, such as a recently-published organic flocculation method

499 (Calgua et al. 2013) would very likely improve the effectiveness of the viral markers for

500 detecting sewage contamination.

501 The performance measures calculated in this study show that many of the methods

502 designed to detect contamination a human source, i.e. human viruses and FRNAPH genotype II,

503 had good $(>80 \%)$ to excellent specificity, meaning that they did not detect their target in waste

504 from other host species (false-positives were infrequent). On the other hand, NPV provided a

505 much more critical assessment of the markers in the face of a high percentage of non-detect

506 results from the viruses. NPV measures the proportion of true-negative results among all

507 negative results, and is therefore lowered by false-negative results (failure to detect the target

508 when it should be present). NPVs for the human viruses in all samples were generally in the

509 range of $35-45 \%$, even though specificity was generally $>85 \%$ to $100 \%$. This result suggests that

510 when viruses are detected in water samples they can be useful tools for identifying the source of

511 pollution; however, when using the sample volumes and concentration methods employed in this

512 study, water samples with undetectable or non-quantifiable viral concentrations cannot be 
Revised VJH 03/04/13

513 assumed to have no human source of pollution. These results agree with recent calculations of

514 detection limits of HPyVs in sewage diluted in environmental water samples. QPCR for HPyVs

515 was generally not sensitive enough to detect sewage contamination at levels corresponding to

516 elevated risk of norovirus infection, which was (calculated by quantitative microbial risk

517 assessment (Staley et al. 2012).

518 The performance of bacteriophage-based methods for detecting human contamination

519 varied from highly specific but insensitive (MB-55) to relatively sensitive but nonspecific

520 (GB124). FRNAPH genotype II had the best performance of the bacteriophages, but, like many

521 of the methods, was not sensitive toward singleton samples containing a human fecal source,

522 indicating that these phages are not ubiquitously distributed in the human population sampled.

523 An advantage of the bacteriophage methods as performed in this study is that the viruses are

524 known to be viable, as a culture step is utilized. The disadvantage of culture methods is that they

525 do not return rapid results, unlike the several-hour turnaround time of qPCR methods that are

526 directly applied to nucleic acid extracted from a water sample. FRNAPH genotyping as

527 performed here requires manipulations for reverse-trancriptase PCR that adds to the time and

528 labor of the culture method. Detection of specific FRNAPH genotypes directly by RT-PCR,

529 without the culture step, has been demonstrated in wastewater (Ogorzaly and Gantzer 2006) and

530 highly polluted river water (Ogorzaly et al. 2009); however, the direct RT-PCR methodology can

531 be less sensitive than the method which includes a culture step, and was therefore not employed

532 here.

533 Some of the viruses were measured by more than one method or laboratory, i.e. EV was

534 tested by four labs and four methods, HAdV by three labs and two methods, and NoV GII by two

535 labs and two methods. EV was the most subject to performance variability, as the EV_USC and 
Revised VJH 03/04/13

536 EV_SCCWRP (unacidified) results were more sensitive than those of the other labs when all

537 samples were considered; however, their specificity notably PPVs were significantly lower than

538 those of other laboratories. The false-positive results for EV_USC and EV_SCCWRP were

539 exclusively against challenge samples containing pig feces, and these two methods used a

540 common set of primers and probe. Sensitivity and PPV were notably lower for the EV_USC and

541 EV-SCCWRP methods in singleton samples than for the dataset containing all samples, which

542 included four samples of combined human and pig waste that were not part of the singleton

543 dataset. HAdV was more sensitive to human contamination in singleton samples than any of the

544 EV methods, and results were consistent for the two labs that measured HAdV by qPCR. Note

545 that one laboratory (TetraTech) acidified samples prior to filtration while the other did not;

546 however, the performance characteristics were not different between the two methods, which

547 used the same primer and probe combination. HPyV was detected at about the same frequency

548 by the two laboratories that tested them, both of which employed the same methods, and showed

549 the typical virus pattern of low sensitivity and NPV, but high specificity and PPV. NoV GII was

550 not detected by either laboratory that tested it (Stanford or UNC-CH).

551 The agreement at the sample level among the tests and laboratories reveals some

552 interesting results. Only the norovirus methods, which failed to identify any positive samples,

553 were in complete agreement for each sample, and this included NoV GI and NoVGII. Results for

554 the two EV methods with high false-positive rates were significantly associated; however, much

555 of the agreement was due to false-positive results from pig samples. Results of HAdV testing

556 from the two laboratories that ran qPCR assays (Stanford and TetraTech) were correlated, but

557 not results from UNC-CH-IMS, which ran conventional PCR. HPyV results were not correlated

558 at the sample level, but results from one laboratory running $\mathrm{HPyV}$ were correlated with results 
Revised VJH 03/04/13

559 from all three laboratories running HAdV. It is not surprising that agreement at the sample level

560 was not generally achieved due to level of target viruses in the samples, which was generally

561 near the LOD for the methods.

562 Another interesting aspect of this study was differences among the laboratories in data

563 generation and handling. Some laboratories ran analyses in duplicate, while others ran triplicates.

564 Although most laboratories required either two positive duplicates or two of three triplicates to

565 call a positive result, two participants called samples with signal in one of two duplicates

566 positive. This discrepancy highlights the need for method standardization across laboratories that

567 carry out MST.

In this study, water was spiked with a level of fecal waste intended to mimic a plausible

569 level of surface water contamination, i.e. an amount that resulted in $\sim 2,000 \mathrm{CFU} \cdot 100 \mathrm{ml}^{-1}$

570 enterococci in the challenge samples (Boehm et al. 2013). This goal was not always achieved

571 because of the inherent variability of enterococci in the waste, and enterococci concentrations in

572 challenge samples spiked only with sewage or septage ranged from 23 (1:10 dilution of sewage)

573 to 1015 (septage) $\mathrm{CFU} \cdot 100 \mathrm{ml}^{-1}$. Although the singleton challenge samples containing human

574 feces had higher levels of enterococci than sewage and septage samples $\left(\sim 6000 \mathrm{CFU} \bullet 100 \mathrm{ml}^{-1}\right)$,

575 viruses were more often detected in septage and sewage than in human feces. Septage and

576 sewage are composite samples from many individuals; therefore they are more likely to contain a

577 target that is sporadically distributed in the population than a fecal sample from an individual,

578 although it should be noted that the human fecal sample used here was a composite from twelve

579 individuals. The inconsistent detection of human viruses in this study is supported by a previous

580 study in which the LOD for HPyVs corresponded to 1,000 to 10,000-fold dilution of sewage

581 containing between $\sim 800-5,000 \mathrm{CFU} \bullet 100 \mathrm{ml}^{-1}$ enterococci (Harwood et al. 2009). In the 2009 
Revised VJH 03/04/13

582 study, $500 \mathrm{ml}$ rather than $50 \mathrm{ml}$ of diluted sewage was processed; therefore, consistent detection

583 of HPyVs and, presumable, the other viruses requires more concentrated sewage samples than

584 those used in the current study.

585 While the specificity and PPV of many of the virus methods is encouraging, the low 586 sensitivity and NPV indicate that better concentration methods are needed if they are to be 587 reliable MST markers. Observed human virus concentrations in sewage estimated by qPCR span 588 a broad range (all concentrations expressed in gene copies $\bullet \mathrm{L}^{-1}$ ), e.g. enteroviruses from $\sim 10^{1}-$ $58910^{8}$ (Katayama et al. 2008, Wolf et al. 2010); noroviruses from $\sim 5 \times 10^{3}-10^{9}$ (da Silva et al. 590 2007, Katayama et al. 2008), adenoviruses from $\sim 10^{1}-5 \times 10^{5}$ (Katayama et al. 2008, Wolf et al. 5912010 , Fong et al. 2010), and HPyVs $\sim 10^{7}$ (McQuaig et al. 2009) (reviewed in Chapter 5: Viruses 592 as Tracers of Fecal Contamination (McQuaig and Noble 2011). Virus concentrations in surface 593 waters tend to be low except when sewage contamination is present (all concentrations expressed

594 in gene copies $\mathrm{L}^{-1}$ ), e.g. adenoviruses detectable to $\sim 10^{2}$ and enteroviruses at $10^{1}-10^{2}$ (Sassoubre 595 et al. 2012); HPyVs undetectable to $\sim 10^{6}$ (McQuaig et al. 2012, McQuaig et al. 2009); norovirus

596 Group I at $10^{3}$ (Sauer et al. 2011). The practice of concentrating large volumes (40 L or more) of 597 surface water is commonly used for quantifying viruses in surface waters (e.g. (Jiang et al. 598 2001)), although the strategy of capturing viruses on negatively charged membrane filters has 599 allowed effective use of 500 to 1,000 ml volumes (McQuaig et al. 2012, Katayama et al. 2002, 600 Rigotto et al. 2009), which is less expensive and labor-intensive than using larger volumes. The 601 results of this study and others (Staley et al. 2012, Harwood et al. 2009), however, indicate that 602 greater concentration factors from surface water samples must be achieved for viral targets to be 603 effective MST markers. Alternative methods for concentration of viruses from surface waters 604 include hollow fiber ultrafiltration (Leskinen et al. 2010, Rajal et al. 2007, Liu et al. 2012, 
Revised VJH 03/04/13

605 Rhodes et al. 2011), electropositive filters such as the NanoCeram ${ }^{\circledR}$ cartridge specified in

606 USEPA Method 1615 (USEPA 2010), and skim milk flocculation (Calgua et al. 2008). The

607 necessity for secondary and/or tertiary steps to concentrate nucleic acids and/or to remove

608 inhibitors must also be taken into consideration (Jiang et al. 2001, McQuaig and Noble 2011,

609 Rhodes et al. 2011).

610 5. Conclusions

611 - Host-specific viruses tended to have high specificity and PPV, but low sensitivity and 612 NPV owing to their uncommon occurrence in their hosts. These findings suggest that 613 when viral markers are detected they can be useful tools for identifying human sources of 614 pollution, however, when viral markers are not detected, human sources of pollution 615 cannot be ruled out.

616 - Host-specific bacteriophage and FRNAPH genotyping methods had moderate specificity 617 and sensitivity; however, they tended to cross react with various non-target hosts. Larger 618 sample sizes may improve sensitivity and negative predictive values.

619 - Some host-associated viruses were tested by more than one laboratory, and while their 620 results did not agree completely, several were significantly associated in challenge fecal samples. Inter-laboratory variation is not surprising given the low levels of viruses presumably in the samples.

- Concentration methods that allow quantitative recovery of viruses while avoiding concentration of substances that inhibit the PCR will be necessary to allow researchers and regulatory agencies to take advantage of the specificity of viruses in MST efforts.

\section{Acknowledgments}

627 Funding for this project has been provided in part through an agreement with the California State 
Revised VJH 03/04/13

Water Resources Control Board. The contents of this document do not necessarily reflect the views and policies of the California State Water Resources Control Board, nor does mention of trade names or commercial products constitute endorsement or recommendation for use. UNC-

$631 \mathrm{CH}$ acknowledges the help of Neil Bhathela in analyses. Tetra Tech acknowledges Qiagen for 632 the sponsoring of Qiagen QIAamp MinElute Virus Spin Kit and Quantifast Pathogen PCR + IC 633 kits.

\section{References}

635 Wade, T.J., Calderon, R.L., Sams, E., Beach, M., Brenner, K.P., Williams, A.H. and Dufour, 636 A.P. (2006) Rapidly measured indicators of recreational water quality are predictive of 637 swimming-associated gastrointestinal illness. Environmental Health Perspectives 114, 24-28.

638 Wade, T.J., Pai, N., Eisenberg, J.N.S. and Colford Jr, J.M. (2003) Do U.S. Environmental 639 Protection Agency water quality guidelines for recreational waters prevent gastrointestinal 640 illness? A systematic review and meta-analysis. Environmental Health Perspectives 111, 11026411109.

642 Kay, D., Fleisher, J.M., Jones, F., Wyer, M., Godfree, A., Zelenauch-Jacquotte, Z. and Shore, R. 643 (1994) Predicting likelihood of gastroenteritis from sea bathing: results from randomized 644 exposure. Lancet 344, 904-909.

645 Boehm, A.B., Fuhrman, J.A., Mrse, R.D. and Grant, S.B. (2003) A tiered approach for the 646 identification of a human fecal pollution source at a recreational beach: Case study at Avalon 647 Bay, Catalina Island, California. Environmental Science and Technology 37, 673-680.

648 Noble, R.T. and Fuhrman, J.A. (2001) Enteroviruses detected by reverse transcriptase 649 polymerase chain reaction from the coastal waters of Santa Monica Bay, California: low 650 correlation to bacterial indicator levels. Hydrobiologia 460, 175-184.

651 Jiang, S.C. and Chu, W. (2004) PCR detection of pathogenic viruses in southern California urban 652 rivers. J Appl Microbiol 97(1), 17-28.

653 McQuaig, S., Griffith, J. and Harwood, V.J. (2012) Association of fecal indicator bacteria with 654 human viruses and microbial source tracking markers at coastal beaches impacted by nonpoint 655 source pollution. Appl Environ Microbiol 78(18), 6423-6432.

656 Jiang, S.C., Noble, R. and Chui, W.P. (2001) Human adenoviruses and coliphages in urban 657 runoff-impacted coastal waters of Southern California. Appl. Environ. Microbiol. 67, 179-184. 
Revised VJH 03/04/13

658

659

660

661

662

663

664

665

666

667

668

669

670

671

672

673

674

675

676

677

678

679

680

681

682

683

684

685

686

687

688

689

Colford, J.M., Jr, Wade, T.J., Schiff, K.C., Wright, C.C., Griffith, J.G., Sandhu, S.K., Burns, S., Hayes, J., Sobsey, M., Lovelace, G. and Weisberg, S.B. (2007) Water quality indicators and the risk of illness at non-point source beaches in Mission Bay, California. Epidemiology 18, 27-35.

WHO (2003) Guidelines for Safe Recreational Water Environments, World Health Organization, Geneva.

Westrell, T., Dusch, V., Ethelberg, S., Harris, J., Hjertqvist, M., Jourdan-da Silva, N., Koller, A., Lenglet, A., Lisby, M. and Vold, L. (2010) Norovirus outbreaks linked to oyster consumption in the United Kingdom, Norway, France, Sweden and Denmark, 2010. Euro Surveill 15(12), 1-4.

Noble, R.T., Allen, S.M., Blackwood, A.D., Chu, W., Jiang, S.C., Lovelace, G.L., Sobsey, M.D., Stewart, J.R. and Wait, D.A. (2003) Use of viral pathogens and indicators to differentiate between human and non-human fecal contamination in a microbial source tracking comparison study. J Water Health 1(4), 195-207.

Savichtcheva, O. and Okabe, S. (2006) Alternative indicators of fecal pollution: Relations with pathogens and conventional indicators, current methodologies for direct pathogen monitoring and future application perspectives. Water Research 40(13), 2463-2476.

Walters, S.P., Yamahara, K.M. and Boehm, A.B. (2009) Persistence of nucleic acid markers of health-relevant organisms in seawater microcosms: implications for their use in assessing risk in recreational waters. Water Res 43(19), 4929-4939.

Pelleieux, S., Bertrand, I., Skali-Lami, S., Mathieu, L., Francius, G. and Gantzer, C. (2012) Accumulation of MS2, GA, and Qbeta phages on high density polyethylene (HDPE) and drinking water biofilms under flow/non-flow conditions. Water Res 46(19), 6574-6584.

Boudaud, N., Machinal, C., David, F., Freval-Le Bourdonnec, A., Jossent, J., Bakanga, F., Arnal, C., Jaffrezic, M.P., Oberti, S. and Gantzer, C. (2012) Removal of MS2, Qbeta and GA bacteriophages during drinking water treatment at pilot scale. Water Res 46(8), 2651-2664.

Cox, P., Griffith, M., Angles, M., Deere, D. and Ferguson, C. (2005) Concentrations of pathogens and indicators in animal feces in the Sydney watershed. Appl Environ Microbiol 71(10), 5929-5934.

McQuaig, S.M., Scott, T.M., Harwood, V.J., Farrah, S.R. and Lukasik, J.O. (2006) Detection of human-derived fecal pollution in environmental waters by use of a PCR-based human polyomavirus assay. Appl Environ Microbiol 72(12), 7567-7574.

McQuaig, S.M., Scott, T.M., Lukasik, J.O., Paul, J.H. and Harwood, V.J. (2009) Quantification of human polyomaviruses JC Virus and BK Virus by TaqMan quantitative PCR and comparison 
Revised VJH 03/04/13

690

691

692

693

694

695

696

697

698

699

700

701

702

703

704

705

706

707

708

709

710

711

712

713

714

715

716

717

718

719

720

721

to other water quality indicators in water and fecal samples. Appl Environ Microbiol 75(11), 3379-3388.

Bofill-Mas, S., Albinana-Gimenez, N., Clemente-Casares, P., Hundesa, A., Rodriguez-Manzano, J., Allard, A., Calvo, M. and Girones, R. (2006) Quantification and stability of human adenoviruses and polyomavirus JCPyV in wastewater matrices. Appl Environ Microbiol 72(12), 7894-7896.

Staley, C., Gordon, K.V., Schoen, M.E. and Harwood, V.J. (2012) Performance of two quantitative PCR methods for microbial source tracking of human sewage and implications for microbial risk assessment in recreational waters. Appl Environ Microbiol 78(20), 7317-7326.

Harwood, V.J., Brownell, M., Wang, S., Lepo, J., Ellender, R.D., Ajidahun, A., Hellein, K.N., Kennedy, E., Ye, X. and Flood, C. (2009) Validation and field testing of library-independent microbial source tracking methods in the Gulf of Mexico. Water Res 43(19), 4812-4819.

Wong, K., Fong, T.T., Bibby, K. and Molina, M. (2012) Application of enteric viruses for fecal pollution source tracking in environmental waters. Environ Int 45, 151-164.

Melnick, J.L. and Rennick, V. (1980) Infectivity titers of enterovirus as found in human stools. J Med Virol 5(3), 205-220.

Wyn-Jones, A.P., Carducci, A., Cook, N., D'Agostino, M., Divizia, M., Fleischer, J., Gantzer, C., Gawler, A., Girones, R., Holler, C., de Roda Husman, A.M., Kay, D., Kozyra, I., Lopez-Pila, J., Muscillo, M., Nascimento, M.S., Papageorgiou, G., Rutjes, S., Sellwood, J., Szewzyk, R. and Wyer, M. (2011) Surveillance of adenoviruses and noroviruses in European recreational waters. Water Res 45(3), 1025-1038.

Stewart, J.R., Gast, R.J., Fujioka, R.S., Solo-Gabriele, H.M., Meschke, J.S., Amaral-Zettler, L.A., Del Castillo, E., Polz, M.F., Collier, T.K., Strom, M.S., Sinigalliano, C.D., Moeller, P.D. and Holland, A.F. (2008) The coastal environment and human health: microbial indicators, pathogens, sentinels and reservoirs. Environ Health 7 Suppl 2, S3.

Soller, J.A., Bartrand, T., Ashbolt, N.J., Ravenscroft, J.E. and Wade, T.J. (2010) Estimating the primary etiologic agents in recreational freshwaters impacted by human sources of faecal contamination. Water Research 44(16), 4736-4747.

Sinclair, R.G., Jones, E.L. and Gerba, C.P. (2009) Viruses in recreational water-borne disease outbreaks: a review. Journal of Applied Microbiology 107(6), 1769-1780.

Atmar, R.L. and Estes, M.K. (2006) The epidemiologic and clinical importance of norovirus infection. Gastroenterol Clin North Am 35(2), 275-290, viii. 
Svraka, S., Duizer, E., Vennema, H., de Bruin, E., van der Veer, B., Dorresteijn, B. and Koopmans, M. (2007) Etiological role of viruses in outbreaks of acute gastroenteritis in The Netherlands from 1994 through 2005. J Clin Microbiol 45(5), 1389-1394.

Reynolds, K.A., Roll, K., Fujioka, R.S., Gerba, C.P. and Pepper, I.L. (1998) Incidence of enteroviruses in Mamala Bay, Hawaii using cell culture and direct polymerase chain reaction methodologies. Canadian Journal of Microbiology 44(6), 598-604.

Moce-Llivina, L., Lucena, F. and Jofre, J. (2005) Enteroviruses and bacteriophages in bathing waters. Appl Environ Microbiol 71(11), 6838-6844.

Sassoubre, L.M., Love, D.C., Silverman, A.I., Nelson, K.L. and Boehm, A.B. (2012)

Comparison of enterovirus and adenovirus concentration and enumeration methods in seawater from Southern California, USA and Baja Malibu, Mexico. Journal of Water and Health in press.

Hundesa, A., Maluquer de Motes, C., Bofill-Mas, S., Albinana-Gimenez, N. and Girones, R. (2006) Identification of human and animal adenoviruses and polyomaviruses for determination of sources of fecal contamination in the environment. Appl Environ Microbiol 72(12), 78867893.

Wetz, J.J., Lipp, E.K., Griffin, D.W., Lukasik, J., Wait, D., Sobsey, M.D., Scott, T.M. and Rose, J.B. (2004) Presence, infectivity, and stability of enteric viruses in seawater: relationship to marine water quality in the Florida Keys. Mar Pollut Bull 48(7-8), 698-704.

Skraber, S., Gassilloud, B., Schwartzbrod, L. and Gantzer, C. (2004) Survival of infectious Poliovirus-1 in river water compared to the persistence of somatic coliphages, thermotolerant coliforms and Poliovirus-1 genome. Water Res 38(12), 2927-2933.

Keswick, B.H., Gerba, C.P., DuPont, H.L. and Rose, J.B. (1984) Detection of enteric viruses in treated drinking water. Appl Environ Microbiol 47(6), 1290-1294.

Thurston-Enriquez, J.A., Haas, C.N., Jacangelo, J., Riley, K. and Gerba, C.P. (2003) Inactivation of feline calicivirus and adenovirus type 40 by ultraviolet radiation. Applied and Environemntal Microbiology 69, 577-582.

Bofill-Mas, S., Pina, S. and Girones, R. (2000) Documenting the epidemiologic patterns of polyomaviruses in human populations by studying their presence in urban sewage. Appl. Environ. Microbiol. 66, 238-245.

Markowitz, R., Thompson, H., Mueller, J., Cohen, J. and WS, D. (1993) Incidence of BK virus and JC virus viruria in human immunodeficiency virus-infected and -uninfected subjects. J. Infect. Dis. 167, 13-20. 
Revised VJH 03/04/13

754

755

756

757

758

759

760

761

762

763

764

765

766

767

768

769

770

771

772

773

774

775

776

777

778

779

780

781

782

783

784

Polo, C., Perez, J.L., Mielnichuck, A., Fedele, C.G., Niubo, J. and Tenorio, A. (2004) Prevalence and patterns of polyomavirus urinary excretion in immunocompetent adults and children. . Clin. Microbiol. Infect. 10, 640-644.

Vanchiere, J.A., Abudayyeh, S., Copeland, C.M., Lu, L.B., Graham, D.Y. and Butel, J.S. (2009) Polyomavirus shedding in the stool of healthy adults. J Clin Microbiol 47(8), 2388-2391.

Vanchiere, J.A., Nicome, R.K., Greer, J.M., Demmler, G.J. and Butel, J.S. (2005) Frequent detection of polyomaviruses in stool samples from hospitalized children. J Infect Dis 192(4), 658-664.

Gourmelon, M., Caprais, M.P., Mieszkin, S., Marti, R., Wery, N., Jarde, E., Derrien, M., JadasHecart, A., Communal, P.Y., Jaffrezic, A. and Pourcher, A.M. (2010) Development of microbial and chemical MST tools to identify the origin of the faecal pollution in bathing and shellfish harvesting waters in France. Water Res 44(16), 4812-4824.

Jofre, J., Stewart, J.R. and Grabow, W. (2011) Microbial Source Tracking: Methods, Applications, and Case Studies. Hagedorn, C., Blanch, A.R. and Harwood, V.J. (eds), pp. 137156, Springer Publishing Co., New York.

Anon (2000) Water Quality. Detection and Enumeration of Bacteriophages-Part 2: Enumeration of Somatic Coliphages., International Organisation for Standardisation, Geneva, Switzerland.

Anon (2001) Water Quality. Detection and Enumeration of Bacteriophages-Part 4: Enumeration of Bacteriophages Infecting Bacteroides fragilis, International Organisation for Standardisation, Geneva, Switzerland.

Hsu, F.C., Shieh, Y.S., van Duin, J., Beekwilder, M.J. and Sobsey, M.D. (1995) Genotyping male-specific RNA coliphages by hybridization with oligonucleotide probes. Applied and Environmental Microbiology 61(11), 3960-3966.

Boehm, A.B., Van de Werfhorst, L.C., Griffith, J.F., Holden, P.A., Jay, J.A., Shanks, O.C., Wang, D. and Weisberg, S.B. (2013) Performance of Forty-Three Microbial Source Tracking Methods: A Twenty-Seven Lab Evaluation Study. Water Research.

Stoeckel, D.M. and Harwood, V.J. (2007) Performance, design, and analysis in microbial source tracking studies. Appl Environ Microbiol 73(8), 2405-2415.

USEPA (2002) Method 1600: Enterococci in water by membrane filter using membrane enterococcus indoxyl-B-D-Glucoside agar (mEI). . USEPA (ed), Office of Water, Washington D. C. 
Mendez, J., Audicana, A., Isern, A., Llaneza, J., Moreno, B., Tarancon, M.L., Jofre, J. and Lucena, F. (2004) Standardised evaluation of the performance of a simple membrane filtrationelution method to concentrate bacteriophages from drinking water. J Virol Methods 117(1), 1925 .

Katayama, H., Shimasaki, A. and Ohgaki, S. (2002) Development of a virus concentration method and its application to detection of enterovirus and norwalk virus from coastal seawater. Appl Environ Microbiol 68(3), 1033-1039.

Gregory, J.B., Litaker, R.W. and Noble, R.T. (2006) Rapid one-step quantitative reverse transcriptase PCR assay with competitive internal positive control for detection of enteroviruses in environmental samples. Appl Environ Microbiol 72(6), 3960-3967.

Fuhrman, J.A., Liang, X.L. and Noble, R.T. (2005) Rapid detection of enteroviruses in small volumes of natural waters by real-time quantitative reverse transcriptase PCR. Applied and Environemntal Microbiology 71(8), 4523-4530.

Mauffret, A., Caprais, M.P. and Gourmelon, M. (2012) Relevance of Bacteroidales and Fspecific RNA bacteriophages for efficient fecal contamination tracking at the level of a catchment in France. Appl Environ Microbiol 78(15), 5143-5152.

Cao, Y., JF Griffith, S Dorevitch and Weisberg., S. (2012) Effectiveness of qPCR permutations, internal controls and dilution as means for minimizing the impact of inhibition while measuring Enterococcus in environmental waters. J Appl Microbiol 113(1), 66-75.

De Leon, R., Y. S. Sheih, R. S. Baric and Sobsey, M.D. (1990) Detection of enteroviruses and hepatitus A virus in environmental samples by gene probes and polymerase chain reaction. Conference, P.o.t.W.Q. (ed), pp. 833-853.

Sivaganesan, M., Haugland, R.A., Chern, E.C. and Shanks, O.C. (2010) Improved strategies and optimization of calibration models for real-time PCR absolute quantification. Water Res 44(16), 4726-4735.

Jothikumar, N., Cromeans, T.L., Hill, V.R., Lu, X., Sobsey, M.D. and Erdman, D.D. (2005) Quantitative real-time PCR assays for detection of human adenoviruses and identification of serotypes 40 and 41. Appl Environ Microbiol 71(6), 3131-3136.

da Silva, A.K., Le Saux, J.C., Parnaudeau, S., Pommepuy, M., Elimelech, M. and Le Guyader, F.S. (2007) Evaluation of removal of noroviruses during wastewater treatment, using real-time reverse transcription-PCR: different behaviors of genogroups I and II. Appl Environ Microbiol 73(24), 7891-7897. 
Jothikumar, N., Lowther, J.A., Henshilwood, K., Lees, D.N., Hill, V.R. and Vinje, J. (2005b) Rapid and sensitive detection of noroviruses by using TaqMan-based one-step reverse transcription-PCR assays and application to naturally contaminated shellfish samples. Appl Environ Microbiol 71(4), 1870-1875.

Kageyama, T., Kojima, S., Shinohara, M., Uchida, K., Fukushi, S., Hoshino, F.B., Takeda, N. and Katayama, K. (2003) Broadly reactive and highly sensitive assay for Norwalk-like viruses based on real-time quantitative reverse transcription-PCR. J Clin Microbiol 41(4), 1548-1557.

Donaldson, K.A., Griffin, D.W. and Paul, J.H. (2002) Detection, quantitation and identification of enteroviruses from surface waters and sponge tissue from the Florida Keys using real-time RT-PCR. Water Res 36(10), 2505-2514.

Xu, W., McDonough, M.C. and Erdman, D.D. (2001) Species-Specific Identification of Human Adenoviruses by a Multiplex PCR Assay. Journal of Clinical Microbiology 39(4), 1686.

Ebdon, J., Muniesa, M. and Taylor, H. (2007) The application of a recently isolated strain of Bacteroides (GB-124) to identify human sources of faecal pollution in a temperate river catchment. Water Res 41(16), 3683-3690.

Vijayavel, K., Fujioka, R., Ebdon, J. and Taylor, H. (2010) Isolation and characterization of Bacteroides host strain HB-73 used to detect sewage specific phages in Hawaii. Water Res 44(12), 3714-3724.

Gourmelon, M., Caprais, M.P., Segura, R., Le Mennec, C., Lozach, S., Piriou, J.Y. and Rince, A. (2007) Evaluation of two library-independent microbial source tracking methods to identify sources of fecal contamination in French estuaries. Appl Environ Microbiol 73(15), 4857-4866.

Ogorzaly, L. and Gantzer, C. (2006) Development of real-time RT-PCR methods for specific detection of F-specific RNA bacteriophage genogroups: application to urban raw wastewater. J Virol Methods 138(1-2), 131-139.

Bialasiewicz, S., Whiley, D.M., Lambert, S.B., Nissen, M.D. and Sloots, T.P. (2009) Detection of BK, JC, WU, or KI polyomaviruses in faecal, urine, blood, cerebrospinal fluid and respiratory samples. J Clin Virol 45(3), 249-254.

Calgua, B., Rodriguez-Manzano, J., Hundesa, A., Sunen, E., Calvo, M., Bofill-Mas, S. and Girones, R. (2013) New methods for the concentration of viruses from urban sewage using quantitative PCR. J Virol Methods 187(2), 215-221.

Ogorzaly, L., Tissier, A., Bertrand, I., Maul, A. and Gantzer, C. (2009) Relationship between Fspecific RNA phage genogroups, faecal pollution indicators and human adenoviruses in river water. Water Res 43(5), 1257-1264. 
Revised VJH 03/04/13

850

Katayama, H., Haramoto, E., Oguma, K., Yamashita, H., Tajima, A., Nakajima, H. and Ohgaki, S. (2008) One-year monthly quantitative survey of noroviruses, enteroviruses, and adenoviruses in wastewater collected from six plants in Japan. Water Research 42(6-7), 1441.

Wolf, S., Hewitt, J. and Greening, G.E. (2010) Viral Multiplex Quantitative PCR Assays for Tracking Sources of Fecal Contamination. Appl. Environ. Microbiol. 76(5), 1388-1394.

Fong, T.-T., Phanikumar, M.S., Xagoraraki, I. and Rose, J.B. (2010) Quantitative Detection of Human Adenoviruses in Wastewater and Combined Sewer Overflows Influencing a Michigan River. Appl. Environ. Microbiol. 76(3), 715-723.

McQuaig, S.M. and Noble, R.T. (2011) Microbial Source Tracking: Methods, Applications, and Case Studies Hagedorn, C., Blanch, A.R. and Harwood, V.J. (eds), pp. 113-135, Springer, New York.

Sauer, E.P., VandeWalle, J.L., Bootsma, M.J. and McLellan, S.L. (2011) Detection of the human specific Bacteroides genetic marker provides evidence of widespread sewage contamination of stormwater in the urban environment. Water Research 45(14), 4081-4091.

Rigotto, C., Kolesnikovas, C., Moresco, V., Simões, C. and Barardi, C. (2009) Evaluation of HA negatively charged membranes in the recovery of human adenoviruses and hepatitis $\mathrm{A}$ virus in different water matrices. Memórias do Instituto Oswaldo Cruz 104, 970-974.

Leskinen, S.D., Brownell, M., Lim, D.V. and Harwood, V.J. (2010) Hollow-fiber ultrafiltration and PCR detection of human-associated genetic markers from various types of surface water in Florida. Appl Environ Microbiol 76(12), 4116-4117.

Rajal, V.B., McSwain, B.S., Thompson, D.E., Leutenegger, C.M., Kildare, B.J. and Wuertz, S. (2007) Validation of hollow fiber ultrafiltration and real-time PCR using bacteriophage PP7 as surrogate for the quantification of viruses from water samples. Water Res 41(7), 1411-1422.

Liu, P., Hill, V.R., Hahn, D., Johnson, T.B., Pan, Y., Jothikumar, N. and Moe, C.L. (2012) Hollow-fiber ultrafiltration for simultaneous recovery of viruses, bacteria and parasites from reclaimed water. J Microbiol Methods 88(1), 155-161.

Rhodes, E.R., Hamilton, D.W., See, M.J. and Wymer, L. (2011) Evaluation of hollow-fiber ultrafiltration primary concentration of pathogens and secondary concentration of viruses from water. J Virol Methods 176(1-2), 38-45.

USEPA (2010) Method 1615: Measurement of Enterovirus and Norovirus Occurrence in Water by Culture and RT-qPCR. EPA/600/R-10/181, Cincinnati, OH. 
Revised VJH 03/04/13

881 Calgua, B., Mengewein, A., Grunert, A., Bofill-Mas, S., Clemente-Casares, P., Hundesa, A., 882 Wyn-Jones, A.P., López-Pila, J.M. and Girones, R. (2008) Development and application of a 883 one-step low cost procedure to concentrate viruses from seawater samples. Journal of Virological 884 Methods 153(2), 79-83.

885 Monpoeho, S., Maul, A., Mignotte-Cadiergues, B., Schwartzbrod, L., Billaudel, S. and Ferré, V. 886 (2001) Best Viral Elution Method Available for Quantification of Enteroviruses in Sludge by 887 Both Cell Culture and Reverse Transcription-PCR. Applied and Environmental Microbiology 888 67(6), 2484-2488.

889 ISO (1995) Detection and Enumeration of Bacteriophages. Part 1: Enumeration of F specific 890 RNA bacteriophages., International Organisation for Standardisation, Geneva, Switzerland.

$891 \quad$ Figure Legend

892 Figure 1. Concentrations of enterococci ( $\bullet$ ) and somatic coliphage $(\square)$ per filter or $50 \mathrm{~mL}$ 893 challenge samples. Note that all samples containing human feces are on the right of the bottom 894 axis. Presence of phage / virus in the challenge samples is indicated above the enterococci and 895 phage data with different symbols for the different laboratories measuring the virus. Detection 896 of the putative human-specific phage HB73 (\#), MB55 (•), and GB124 (O) are indicated.

897 Detection of human-associated Group II F+ RNA coliphages are indicated (O). Detection of EV 898 in the USC (•) and SCCWRP (non-acid method) (O) laboratories is indicated, no EV detected 899 by other laboratories. The presence of HAdv in the TetraTech ( $\square)$ and Stanford ( $\square$ ) laboratories 900 is indicated, no HAdV detected by UNC. Presence of HPyVs in the TetraTech (•) and USF (O) 901 laboratories is indicated. 
Table 1. Summary of virus, targeted host, and method type. The theoretical limit of detection $\left(\mathrm{LOD}_{\mathrm{T}}\right)$ is expressed as gene copies filter $^{-1}(50 \mathrm{ml}$ samples were filtered $)$ or plaques $\bullet(50 \mathrm{ml})^{-1}$.

\begin{tabular}{|c|c|c|c|c|c|c|}
\hline $\begin{array}{l}\text { Human Virus } \\
\text { Designation \& Lab }\end{array}$ & Virus Type & Target & Method & Primer/Probe sequences & Reference & $\mathbf{L O D}_{\mathrm{T}}$ \\
\hline $\begin{array}{l}\text { EV_Stanford } \\
\text { EV_SCCWRP } \\
\text { EV_SCCWRP }\end{array}$ & Enterovirus & Human & $\begin{array}{l}\text { Reverse } \\
\text { Transcription } \\
\text { QPCR }\end{array}$ & $\begin{array}{l}\text { EVupstream: CCT CCG GCC CCT GAA TG } \\
\text { EVdownstream: ACC GGA TGG CCA ATC CAA } \\
\text { Pan-enterovirus Probe: FAM- ACG GAC ACC } \\
\text { CAA AGT AGT CGG TTC-BHQ }\end{array}$ & $\begin{array}{l}\text { (Walters et al. } \\
\text { 2009, Gregory et } \\
\text { al. 2006, De Leon } \\
\text { et al. 1990) }\end{array}$ & 20 \\
\hline EV_USC & Enterovirus & Human & $\begin{array}{l}\text { Reverse } \\
\text { Transcription } \\
\text { QPCR }\end{array}$ & $\begin{array}{l}\text { EV1 (reverse): GAT TGT CAC CAT AAG CAG } \\
\text { C } \\
\text { EV } 2 \text { (forward): CCC CTG AAT GCG GCT AAT } \\
\text { C } \\
\text { EV Probe: FAM-CGG AAC CGA CTA CTT TGG } \\
\text { GTG TCC GT-BHQ }\end{array}$ & $\begin{array}{l}\text { (Fuhrman et al. } \\
\text { 2005, Monpoeho } \\
\text { et al. 2001) }\end{array}$ & 10 \\
\hline EV_UNC-CH & Enterovirus & Human & $\begin{array}{l}\text { Reverse } \\
\text { Transcription } \\
\text { QPCR }\end{array}$ & $\begin{array}{l}\text { Upstream: GGC CCC TGA ATG CGG CTA AT } \\
\text { Downstream: CAC CGG ATG GCC AAT CCA A } \\
\text { Probe: FAM-CGG ACA CCC AAA GTA GTC } \\
\text { GGT TCC G-TAMRA }\end{array}$ & $\begin{array}{l}\text { (Donaldson et al. } \\
\text { 2002) }\end{array}$ & 15 \\
\hline $\begin{array}{l}\text { HAdV_Stanford } \\
\text { HAdV_TetraTech }^{\mathrm{a}}\end{array}$ & Adenovirus & Human & QPCR & $\begin{array}{l}\text { JTVXF: GGA CGC CTC GGA GTA CCT GAG } \\
\text { JTVXR: ACI GTG GGG TTT CTG AAC TTG TT } \\
\text { JTVXP: FAM-CTG GTG CAG TTC GCC CGT } \\
\text { GCCA-BHQ }\end{array}$ & $\begin{array}{l}\text { (Jothikumar et al. } \\
\text { 2005) }\end{array}$ & 20 \\
\hline $\begin{array}{l}\text { HAdV_UNC- } \\
\text { CH_IMS }\end{array}$ & Adenovirus & Human & $\begin{array}{l}\text { Conventional } \\
\text { PCR }\end{array}$ & $\begin{array}{l}\text { Ad1: TTCCCCATGGCICAYAACAC } \\
\text { Ad2: CCCTGGTAKCCRATRTTGTA }\end{array}$ & (Xu et al. 2001) & 20 \\
\hline NoV GI_UNC-CH & $\begin{array}{l}\text { Norovirus } \\
\text { (Group I) }\end{array}$ & Human & $\begin{array}{l}\text { Reverse } \\
\text { Transcription } \\
\text { QPCR }\end{array}$ & $\begin{array}{l}\text { JJV1F: GCC ATG TTC CGI TGG ATG } \\
\text { JJV1R: TCC TTA GAC G CC ATC ATC AT } \\
\text { JJV1P: FAM-TGT GGA CAG GAG ATC GCA } \\
\text { ATC TC-BHQ }\end{array}$ & $\begin{array}{l}\text { (Jothikumar et al. } \\
\text { 2005b) }\end{array}$ & 15 \\
\hline NoV GII_UNC-CH & $\begin{array}{l}\text { Norovirus } \\
\text { (Group II) }\end{array}$ & Human & $\begin{array}{l}\text { Reverse } \\
\text { Transcription }\end{array}$ & $\begin{array}{l}\text { JJV2F: CAA GAG TCA ATG TTT AGG TGG } \\
\text { ATG AG } \\
\text { COG2R: TCG ACG CCA TCT TCA TTC ACA }\end{array}$ & $\begin{array}{l}\text { (Jothikumar et al. } \\
\text { 2005b, Kageyama } \\
\text { et al. 2003) }\end{array}$ & 15 \\
\hline
\end{tabular}




\begin{tabular}{|c|c|c|c|c|c|c|}
\hline $\begin{array}{l}\text { Human Virus } \\
\text { Designation \& Lab }\end{array}$ & Virus Type & Target & Method & Primer/Probe sequences & Reference & $\mathbf{L O D}_{\mathrm{T}}$ \\
\hline & & & QPCR & $\begin{array}{l}\text { RING2-TP: FAM-TGG GAG GGC GAT CGC } \\
\text { AAT CT-BHQ }\end{array}$ & & \\
\hline NoV GII_Stanford & $\begin{array}{l}\text { Norovirus } \\
\text { (Group II) }\end{array}$ & Human & $\begin{array}{l}\text { Reverse } \\
\text { Transcription } \\
\text { QPCR }\end{array}$ & $\begin{array}{l}\text { QNIF2d: ATG TTC AGR TGG ATG AGR TTC } \\
\text { TCW GA } \\
\text { COG2R: TCG ACG CCA TCT TCA TTC ACA } \\
\text { QNIFS - FAM- AGC ACG TGG GAG GGG ATC } \\
\text { G-TAMRA }\end{array}$ & $\begin{array}{l}\text { (da Silva et al. } \\
\text { 2007, Jothikumar } \\
\text { et al. 2005b, } \\
\text { Kageyama et al. } \\
\text { 2003) }\end{array}$ & 20 \\
\hline $\begin{array}{l}\text { HPyV_USF } \\
\text { HPyV_TetraTech }\end{array}$ & $\begin{array}{l}\text { Polyomaviruses } \\
\text { BK and JC }\end{array}$ & Human & QPCR & $\begin{array}{l}\text { SM2:AGT CTT TAG GGT CTT CTA CCT TT } \\
\text { KGJ3:TCA TCA CTG GCA AAC AT } \\
\text { P6:GGT GCC AAC CTA TGG AAC AG }\end{array}$ & $\begin{array}{l}\text { (McQuaig et al. } \\
\text { 2009) }\end{array}$ & 20 \\
\hline \multicolumn{7}{|l|}{$\begin{array}{l}\text { Bacteriophage and } \\
\text { Lab }\end{array}$} \\
\hline $\begin{array}{l}\text { GB-124_UB \& } \\
\text { FOPH }\end{array}$ & $\begin{array}{l}\text { Bacteroides } \\
\text { GB-124 Phage }\end{array}$ & Human & $\begin{array}{l}\text { Double } \\
\text { Layer Agar }\end{array}$ & NA & $\begin{array}{l}\text { (Anon 2000, } \\
\text { Ebdon et al. } \\
2007)\end{array}$ & 50 \\
\hline WG-5_UB & $\begin{array}{l}\text { Somatic } \\
\text { Coliphage on } \\
\text { host WG-5 }\end{array}$ & Human & $\begin{array}{l}\text { Double } \\
\text { Layer Agar }\end{array}$ & NA & (Anon 2001) & 50 \\
\hline MB-55_WSU & $\begin{array}{l}\text { Enterococcus } \\
\text { Phage on host } \\
\text { MB-55 }\end{array}$ & Human & $\begin{array}{l}\text { Double } \\
\text { Layer Agar }\end{array}$ & NA & $\begin{array}{l}\text { (Vijayavel et al. } \\
\text { 2010) }\end{array}$ & 10 \\
\hline HB-73_WSU & $\begin{array}{l}\text { Enterococcus } \\
\text { Phage on host } \\
\text { HB-73 }\end{array}$ & Human & $\begin{array}{l}\text { Double } \\
\text { Layer Agar }\end{array}$ & NA & $\begin{array}{l}\text { (Vijayavel et al. } \\
\text { 2010) }\end{array}$ & 10 \\
\hline FRNAPH_IFREMER & $\begin{array}{l}\text { F-specific RNA } \\
\text { Bacteriophage } \\
\text { on host } S \text {. } \\
\text { enterica } \text { WG- }\end{array}$ & General & $\begin{array}{l}\text { Double } \\
\text { Layer Agar }\end{array}$ & NA & (ISO 1995) & 25 \\
\hline
\end{tabular}




\begin{tabular}{|c|c|c|c|c|c|c|}
\hline Human Virus & Virus Type & Target & Method & Primer/Probe sequences & Reference & $\mathbf{L O D}_{\mathrm{T}}$ \\
\hline & 49 & & & & & \\
\hline $\begin{array}{l}\text { FRNAPH II_ } \\
\text { IFREMER }\end{array}$ & $\begin{array}{l}\text { Genotype II } \\
\text { FRNAPH }\end{array}$ & Human & $\begin{array}{l}\text { Reverse } \\
\text { Transcription } \\
\text { QPCR on } \\
\text { isolated } \\
\text { plaques }\end{array}$ & $\begin{array}{l}\text { GIIF : TGCAAACCTAACTCGGAATGG } \\
\text { GIIR : AGGAGAGAACGCAGGCCTCTA } \\
\text { GIIP : FAM-TCCCTCTATTTCCTC-MGBNFQ }\end{array}$ & $\begin{array}{l}\text { (Ogorzaly and } \\
\text { Gantzer 2006) }\end{array}$ & NA \\
\hline
\end{tabular}

${ }^{\mathrm{a}}$ Samples were acidified prior to filtration

${ }^{\mathrm{b}}$ Not applicable 
Table 2. All samples (38 singletons and 26 doubletons) used to calculate performance measures including sensitivity, specificity, positive predictive value (PPV) and negative predictive value (NPV). Data for general (non host-specific) fecal indicators are in shaded rows.

$\begin{array}{lllll}\text { Human Viruses } & \text { Sensitivity } & \text { Specificity } & \text { PPV } & \text { NPV } \\ \text { EV_USC (qPCR) } & 13.2 \% & 84.6 \% & 55.6 \% & 40.0 \% \\ \text { EV_UNC-CH (qPCR) } & 0.0 \% & 100.0 \% & \text { NC } & 40.6 \% \\ \text { EV_Stanford (qPCR) } & 0.0 \% & 100.0 \% & \text { NC } & 39.3 \% \\ \text { EV_SCCWRP (qPCR) } & 10.5 \% & 88.5 \% & 57.1 \% & 40.4 \% \\ \text { EV_SCCWRP_acid (qPCR) } & 0.0 \% & 100.0 \% & \text { NC } & 40.6 \% \\ \text { AdV_TetraTech (qPCR) } & 13.2 \% & 100.0 \% & 100.0 \% & 44.1 \% \\ \text { AdV_Stanford (qPCR) } & 5.4 \% & 100.0 \% & 100.0 \% & 40.7 \% \\ \text { AdV_UNC-CH-IMS (PCR) } & 5.3 \% & 100.0 \% & 100.0 \% & 41.9 \% \\ \text { NoV GI_UNC-CH (qPCR) } & 0.0 \% & 100.0 \%{ }^{c} & \text { NC } & 40.6 \% \\ \text { NoV GII_UNC-CH (qPCR) } & 0.0 \% & 100.0 \%{ }^{c} & \text { NC } & 40.6 \% \\ \text { NoV GII_Stanford (qPCR) } & 0.0 \% & 100.0 \%{ }^{c} & \text { NC } & 39.3 \% \\ \text { HPyVs_TetraTech (qPCR) } & 7.9 \% & 100.0 \% & 100.0 \% & 42.6 \% \\ \text { HPyVs_USF (qPCR) } & 10.5 \% & 100.0 \% & 100.0 \% & 43.3 \%\end{array}$

\section{Bacteriophage}

$\begin{array}{lllll}\text { MB-55 } & 0.0 \% & 96.2 \% & 0.0 \% & 39.7 \% \\ \text { HB-73 } & 26.3 \% & 80.8 \% & 66.7 \% & 42.9 \% \\ \text { GB-124 } & 60.5 \% & 57.7 \% & 67.7 \% & 50.0 \% \\ \text { FRNAPH Group II } & 18.4 \% & 84.6 \% & 63.6 \% & 41.5 \% \\ \text { FRNAPH }^{\mathrm{b}} & 21.1 \% & 69.2 \% & 50.0 \% & 37.5 \% \\ \text { somatic coliphage }^{\mathrm{b}} & 71.1 \% & 38.5 \% & 62.8 \% & 47.6 \%\end{array}$

${ }^{a} \mathrm{NC}$ designates no calculation, as the formula would require division by 0 .

${ }^{b}$ These methods are intended to be general indicators of fecal contamination, therefore sensitivity and specificity are provided only for comparison. 
Table 3. Singleton samples only $(n=38)$ used to calculate performance measures including sensitivity, specificity, positive predictive value (PPV) and negative predictive value (NPV). Data for general (non host-specific) fecal indicators are in shaded rows.

$\begin{array}{lllll}\text { Human Viruses } & \text { Sensitivity } & \text { Specificity } & \text { PPV } & \text { NPV } \\ \text { EV_USC (qPCR) } & 8.3 \% & 84.6 \% & 20.0 \% & 66.7 \% \\ \text { EV_UNC-CH (qPCR) } & 0.0 \% & 100.0 \%^{\mathrm{c}} & \mathrm{NC}^{\mathrm{a}} & 68.4 \% \\ \text { EV_Stanford (qPCR) } & 0.0 \% & 100.0 \%^{\mathrm{c}} & \mathrm{NC} & 66.7 \% \\ \text { EV_SCCWRP (qPCR) } & 0.0 \% & 88.5 \% & 0.0 \% & 65.7 \% \\ \text { EV_SCCWRP_acid (qPCR) } & 0.0 \% & 100.0 \% & \mathrm{NC} & 68.4 \% \\ \text { AdV_TetraTech (qPCR) } & 16.7 \% & 100.0 \% & 100.0 \% & 72.2 \% \\ \text { AdV_Stanford (qPCR) } & 16.7 \% & 100.0 \% & 100.0 \% & 70.6 \% \\ \text { AdV_UNC-CH-IMS (PCR) } & 0.0 \% & 100.0 \% & \mathrm{NC} & 68.4 \% \\ \text { NoV GI_UNC-CH (qPCR) } & 0.0 \% & 100.0 \%{ }^{\mathrm{c}} & \mathrm{NC} & 40.6 \% \\ \text { NoV GII_UNC-CH (qPCR) } & 0.0 \% & 100.0 \%{ }^{\mathrm{c}} & \mathrm{NC} & 68.4 \% \\ \text { NoV GII_Stanford (qPCR) } & 0.0 \% & 100.0 \% \mathrm{c} & \mathrm{NC} & 66.7 \% \\ \text { HPyVs_TetraTech (qPCR) } & 8.3 \% & 100.0 \% & 100.0 \% & 70.3 \% \\ \text { HPyVs_USF (qPCR) } & 8.3 \% & 100.0 \% & 100.0 \% & 70.3 \%\end{array}$

\section{Bacteriophage}

$\begin{array}{lllll}\text { MB-55 } & 0.0 \% & 96.2 \% & 0.0 \% & 67.6 \% \\ \text { HB-73 } & 25.0 \% & 80.8 \% & 37.5 \% & 70.0 \% \\ \text { GB-124 } & 66.7 \% & 57.7 \% & 42.1 \% & 78.9 \% \\ \text { FRNAPH Group II } & 0.0 \% & 84.6 \% & 0.0 \% & 64.7 \% \\ \text { FRNAPH }^{\mathrm{b}} & 8.3 \% & 69.2 \% & 11.1 \% & 62.1 \% \\ \text { somatic coliphage }^{\mathrm{b}} & 58.3 \% & 38.5 \% & 30.4 \% & 66.7 \%\end{array}$

${ }^{a} \mathrm{NC}$ designates no calculation, as the formula would require division by 0 .

${ }^{b}$ These methods are intended to be general indicators of fecal contamination.

${ }^{\mathrm{c}}$ Specificity was $100 \%$ because no false-positive results occurred, however, no true-positive results were observed 
Table 4. Results by laboratory for host-associated viruses from methods and samples with results above the LOD $_{\mathrm{T}}$.

\begin{tabular}{|c|c|c|c|c|c|c|c|c|c|}
\hline \multicolumn{2}{|c|}{ EV_USC } & \multicolumn{2}{|c|}{ EV_SCCWRP } & \multicolumn{2}{|c|}{ HAdV_TT } & \multicolumn{2}{|c|}{ HAdV_Stanford } & \multicolumn{2}{|c|}{ HPyV_TT } \\
\hline $\begin{array}{l}\text { Sample } \\
\text { Type }\end{array}$ & $\begin{array}{c}\text { Gene } \\
\text { Copies }^{\text {a }}\end{array}$ & $\begin{array}{c}\text { Sample } \\
\text { Type }\end{array}$ & $\begin{array}{l}\text { Gene } \\
\text { Copies }\end{array}$ & $\begin{array}{c}\text { Sample } \\
\text { Type }\end{array}$ & $\begin{array}{l}\text { Gene } \\
\text { Copies }\end{array}$ & $\begin{array}{c}\text { Sample } \\
\text { Type }\end{array}$ & $\begin{array}{c}\text { Gene } \\
\text { Copies }\end{array}$ & $\begin{array}{c}\text { Sample } \\
\text { Type }\end{array}$ & $\begin{array}{c}\text { Gene } \\
\text { Copies }\end{array}$ \\
\hline pig 1:10 & $2.1 \times 10^{5}$ & pig 1:10 & $3.1 \times 10^{1}$ & sewage & $1.1 \times 10^{2}$ & septage & $7.5 \times 10^{1}$ & $\begin{array}{c}\text { human/cow } \\
10 / 90\end{array}$ & $1.4 \times 10^{2}$ \\
\hline pig & $8.3 \times 10^{5}$ & pig & $3.3 \times 10^{1}$ & septage & $7.8 \times 10^{1}$ & septage & $3.8 \times 10^{1}$ & sewage & $3.4 \times 10^{2}$ \\
\hline $\begin{array}{l}\text { sewage/pig } \\
90 / 10\end{array}$ & $2.7 \times 10^{5}$ & $\begin{array}{c}\text { sewage/pig } \\
90 / 10\end{array}$ & $4.0 \times 10^{1}$ & $\begin{array}{c}\text { sewage/gull } \\
10 / 90\end{array}$ & $2.9 \times 10^{2}$ & & & $\begin{array}{c}\text { human/dog } \\
10 / 90\end{array}$ & $6.3 \times 10^{2}$ \\
\hline sewage & $1.0 \times 10^{6}$ & $\begin{array}{c}\text { sewage/pig } \\
10 / 90\end{array}$ & $1.3 \times 10^{2}$ & $\begin{array}{c}\text { sewage/pig } \\
90 / 10\end{array}$ & $6.7 \times 10^{1}$ & & & & \\
\hline $\begin{array}{l}\text { sewage/pig } \\
10 / 90\end{array}$ & $8.1 \times 10^{5}$ & $\begin{array}{c}\text { sewage/pig } \\
10 / 90\end{array}$ & $3.2 \times 10^{2}$ & $\begin{array}{c}\text { sewage/gull } \\
90 / 10\end{array}$ & $5.2 \times 10^{1}$ & & & & \\
\hline $\begin{array}{l}\text { sewage/pig } \\
90 / 10\end{array}$ & $7.5 \times 10^{4}$ & & & & & & & & \\
\hline $\begin{array}{l}\text { sewage/pig } \\
10 / 90\end{array}$ & $1.2 \times 10^{6}$ & & & & & & & & \\
\hline pig & $2.4 \times 10^{5}$ & & & & & & & & \\
\hline pig $1: 10$ & $4.9 \times 10^{4}$ & & & & & & & & \\
\hline
\end{tabular}




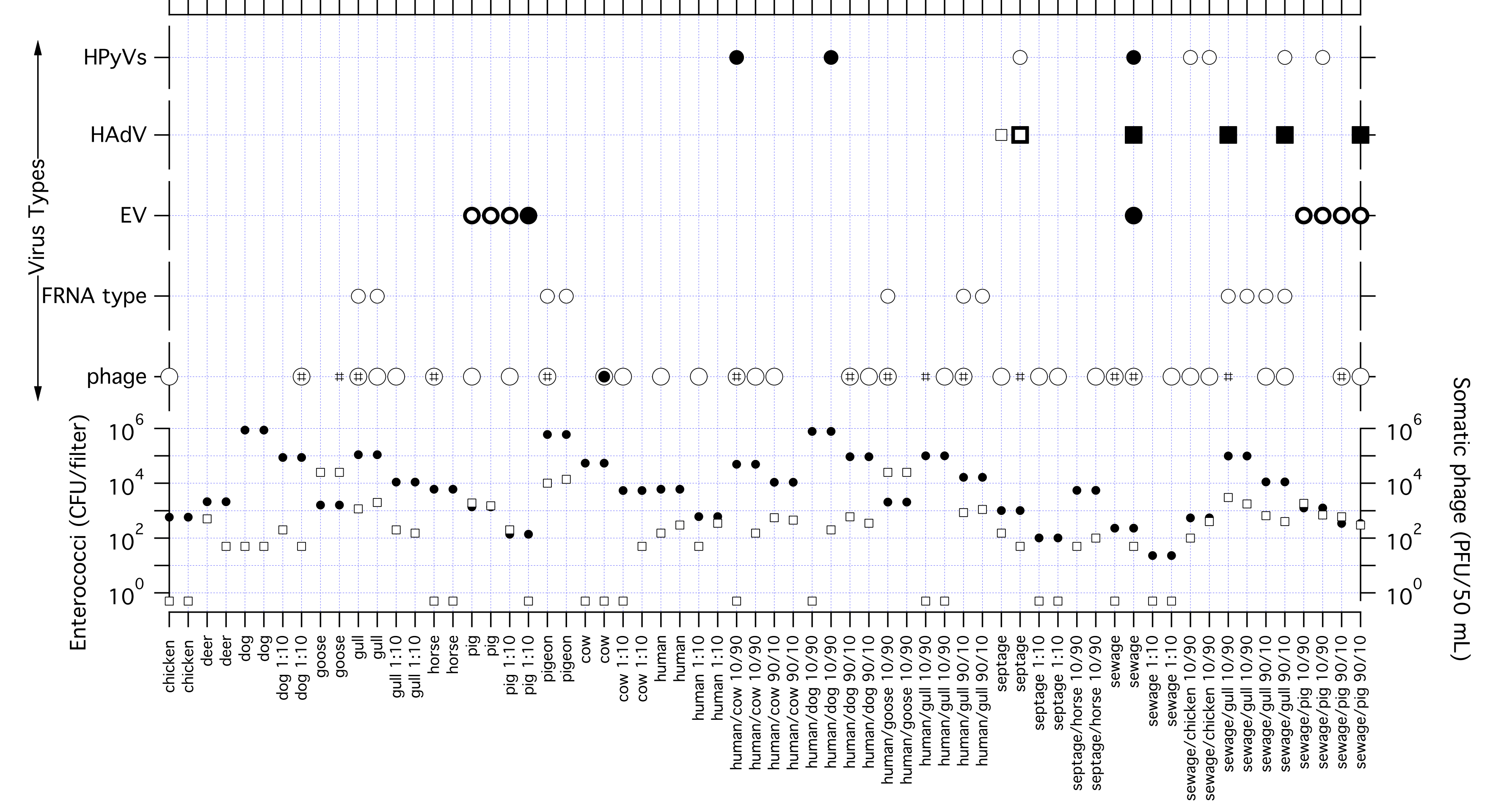

